Article

\title{
The Potential Contribution of Imported Biomass to Renewable Energy Targets in the EU-the Trade-off between Ambitious Greenhouse Gas Emission Reduction Targets and Cost Thresholds
}

\author{
Lotte Visser * (1), Ric Hoefnagels and Martin Junginger \\ Copernicus Institute of Sustainable Development, Utrecht University, 3584 CB Utrecht, The Netherlands; \\ r.hoefnagels@uu.nl (R.H.); h.m.junginger@uu.nl (M.J.) \\ * Correspondence: 1.visser2@uu.nl
}

Received: 19 February 2020; Accepted: 27 March 2020; Published: 7 April 2020

\begin{abstract}
Wood pellets could potentially contribute to bioenergy demand in the European Union (EU). Market cost constraints as well as greenhouse gas (GHG) emission savings thresholds imposed by the European Commission however limit the potential use of pellets. A spatially explicit assessment of import potentials of both pellets and torrefied pellets, based on the growing stock of forestry biomass in the US, Canada, Brazil, Russia and Baltic States, was combined with an analysis of supply chain costs and emissions in order to analyse potentials as limited by different levels of costs and emission constraints. Results show that in case of GHG savings thresholds of $70 \%, 80 \%$ and $85 \%$ the total import potential is reduced to 61 to 24 and $1 \mathrm{Mt}$, respectively. The potential for torrefied pellets is larger in all cases, $44 \mathrm{Mt}$ in the case of an $80 \%$ limit. Import potentials at cost limits of 200, 175, 150 and $125 € / \mathrm{t}$ are reduced from $58 \mathrm{Mt}$ to 52,38 and $9 \mathrm{Mt}$ pellets, respectively, with little difference between pellets and torrefied pellets. This work shows that spatially explicit variation in feedstock availability and logistics has a significant impact on total import potentials and must therefore be included in any assessment of bioenergy potential and trade.
\end{abstract}

Keywords: biomass trade; feedstock availability; supply chain analysis; GHG threshold; supply chain costs; spatially explicit; logistics; import potential

\section{Introduction}

In the European Union (EU), the energy transition is largely shaped by the renewable energy targets set for 2020 in the 2009 Renewable Energy Directive (RED I) and for the period 2020-2030 in its recast (RED II) [1]. In several EU countries, increased utilization of woody biomass for electricity and heat is a means to reaching renewable energy targets [2]. In their long-term vision for a prosperous climate-neutral economy, the European Commission foresees an important role to be played by biomass, especially in sectors which are more difficult to decarbonize such as industry and (heavy) transport, by using biomass for the production of aviation fuel, industrial process heating and bio-based materials and chemicals [3]. These different applications can all be covered by the utilization of sustainably sourced lignocellulosic biomass. A limiting factor in this is the availability of sustainable and affordable feedstock. Discrepancies between supply and demand in different countries have resulted in an emerging trade in fuel wood, wood chips and especially wood pellets between countries and world regions [4,5]. In 2018, the EU supplemented $17 \mathrm{Mt}$ of wood pellet production with the importation of $8 \mathrm{Mt}$ from the US and $2 \mathrm{Mt}$ from other European countries [6]. Increased demand for biobased energy and materials will likely result in further increases in the international wood pellet trade [7]. 
With the introduction of RED II, binding sustainability criteria were established for all bioenergy sectors to ensure sustainable production. These criteria relate to aspects such as supply chain GHG emissions, the risk of indirect land use change and the protection of land with high biodiversity or carbon stock. In contrast to for example indirect land use change (ILUC) criteria, indicators for GHG savings criteria are relatively well defined and quantifiable. Minimum thresholds per end-use type have been defined. The calculation method is standardized including pre-defined fossil fuel comparators and calculation rules [1]. For installations with a rated thermal input $>20 \mathrm{MW}$, the standard is $70 \%$ savings after January 2021 , compared to a predetermined fossil fuel comparator, increasing to $80 \%$ after 2026. Besides the imposed threshold on supply chain GHG emissions, there are market constraints for total supply chain costs. The fact that wood pellet utilization is in competition with fossil energy such as coal and natural gas as well as other renewable energy technologies limits maximum supply chain costs.

As shown in previous studies, the cost and GHG performance of solid biomass depends to a large extent on supply chain design such as the type of feedstock used and transport distances. The US currently is globally the largest exporter of wood pellets, mainly to western Europe [6,8]. With increasing demand, the question is whether new trade routes will emerge, utilizing unused fiber baskets in other world regions. Existing literature studies have concluded that an increase of wood pellet consumption in the EU may result in increased imports from, amongst others, Russia, Canada, Brazil and the US $[7,9,10]$. What these studies however did not take into account is the detailed spatially explicit availability of feedstock and how this impacts supply chain costs and emissions. Emerging trade routes and import potentials can only be assessed by considering detailed mobilization and trade potentials at different cost and emission levels, and by comparing this to market and legislative constraints.

Supply chain costs and emissions could potentially be optimized by introducing additional pre-treatment technologies, such as thermochemical treatment to produce torrefied pellets (TOP). Combustion of pellets is more challenging than coal, introducing issues such as mechanical degradation during storage, efficiency loss resulting from lower energy density and increased ash deposition in boilers [2]. Using TOP instead of white pellets (WP) could reduce some of these issues. TOP have increased grindability and hydrophobicity and a higher energy density, resulting in lower transport costs and emissions [11]. On the other hand, the production of TOP increases processing costs and introduces an additional, energy consuming, processing step. Whether a transition towards using TOP instead of WP results in optimized costs and emissions of bioenergy production depends on the design of specific supply chains. This research will analyse and quantify the potential role for TOP in meeting current and future GHG and cost criteria. This analysis will show whether there are favourable conditions for TOP production and trade, as well as whether production of TOP unlocks increased production areas.

Policy making in the context of climate change can be based on integrated assessment modelling of the impact of different pathways or specific policies on carbon emissions or global warming. European energy system models, such as the Price-Induced Market Equilibrium System (PRIMES) [12], the JRC-EU-TIMES model [13] and global integrated assessment models such as IIASA's Global Biosphere Management Model (GLOBIOM) [14], the IMAGE model framework [15] and the Global Forest Products Model (GFPM) [16] are generally based on default biofuel supply chains, not accounting for supply shifts resulting from increased demand. Whereas these models do account for regional variation in costs of labour, land or capital, the impact of spatial feedstock availability and logistics on biomass costs is not included. The role of biobased energy and materials production in the energy transition can only be understood by incorporating a detailed characterization of logistics required to mobilize large quantities of biomass. The large impact of supply chain design on costs and emissions of bioenergy necessitates the inclusion of spatial impacts in global energy modelling. Sustainable import potential of pellets from different world regions to the Netherlands were amongst others analysed by 
Mai-Moulin et al. [17]. Mai-Moulin et al., however, did not consider the spatial availability of feedstock and the impact of transport networks and distances in detail.

This article is based on the premise that a sharp worldwide reduction in GHG emissions will be pursued and realized, and that biobased energy and materials have an important role to play to achieve the required emission reductions. Within this article, the focus will be on solid biomass in the form of wood pellets, produced from forestry biomass in the US, Canada, Brazil, Russia and the Baltic States and imported to Western Europe. In this study, a spatially explicit assessment is made of import potentials, based on the growing stock of forestry biomass, limited by an exclusion of protected and high-biodiverse land as well as local use for energy and non-energy purposes. These potentials are combined with an explicit assessment of wood pellet supply chain costs and emissions, including the transport requirements from inland locations to export ports. Costs and GHG emission thresholds are applied to calculate potential import quantities to western Europe as well as maximum potential sourcing areas in the different countries for pellets and torrefied pellets.

\section{Materials and Methods}

This work consists of a few different components, see Figure 1. Firstly, supply chain design costs and emissions were calculated for discrete supply chains from selected sourcing countries (United States, Canada, Brazil, Estonia, Latvia, Lithuania, Russia). Certain supply chain design characteristics were varied to analyse the impact on total costs and emissions, specifically the choice between pulpwood and sawmill residues, and the distinction between wood pellets and torrefied pellets. The impact of inland transport distance was also calculated. See Figure 2 for the impact of design variables on the included cost components. Secondly, pellet production potentials were calculated in the different countries based on feedstock availability in forests. These two parts were combined to generate costs and GHG supply curves, including the impact of inland transport. By applying different cost and emission criteria, the total potential availability of pellets under different circumstances was analysed.

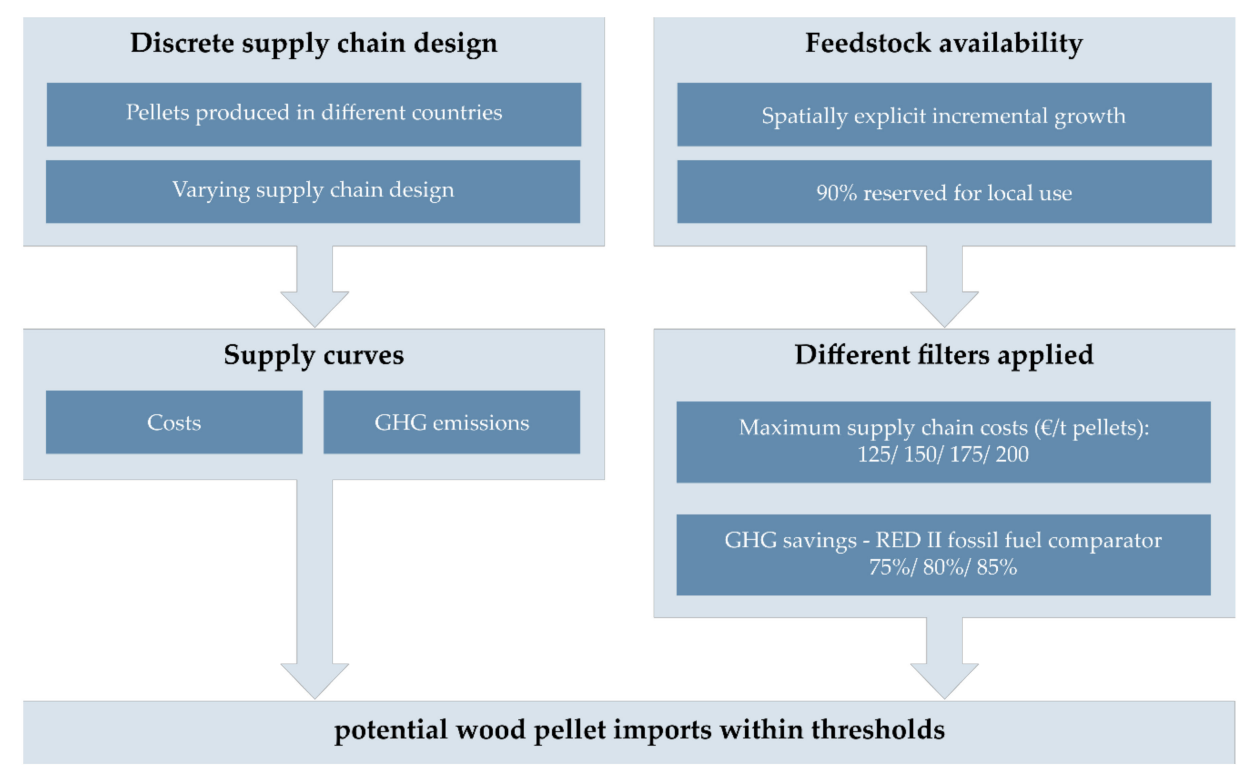

Figure 1. General research framework.

When using "wood pellets" or "pellets" in the remainder of this article, this is always in reference to regular pellets from forestry biomass. The selection of sourcing countries was based on current pellet production and consumption and on the potential for future production increases $[5,7,18,19]$. Supply chain costs and GHG supply curves of potential pellet production and trade were constructed based on the locations of export ports suitable for pellet export, within the including sourcing countries. Results 
from costs and emission analyses were used in the calculation of maximum supply areas and the total potential pellet production that can be supplied from these areas. This potential was calculated based on incremental growth of forestry biomass in spatially explicit forestry areas. Areas assumed high in biodiversity were subtracted from the total area, including protected areas and areas previously untouched by human exploration, considered a good estimation of the extent of primary forests. Of the incremental growth, a share of $90 \%$ was assumed to be reserved for existing local energy and material use. The GHG emission thresholds used were the $70 \%$ and $80 \%$ included in the RED II standards, as well as $85 \%$ in reflection of further tightening of emission criteria. Calculations were based on the fossil fuel comparator for electricity and heat production as outlined by the Joint Research Centre (JRC) [20]. These comparators represent typical or default GHG emissions of fossil electricity and heat production, and are based on a marginal mix of present and perspective power production and feedstocks [20].

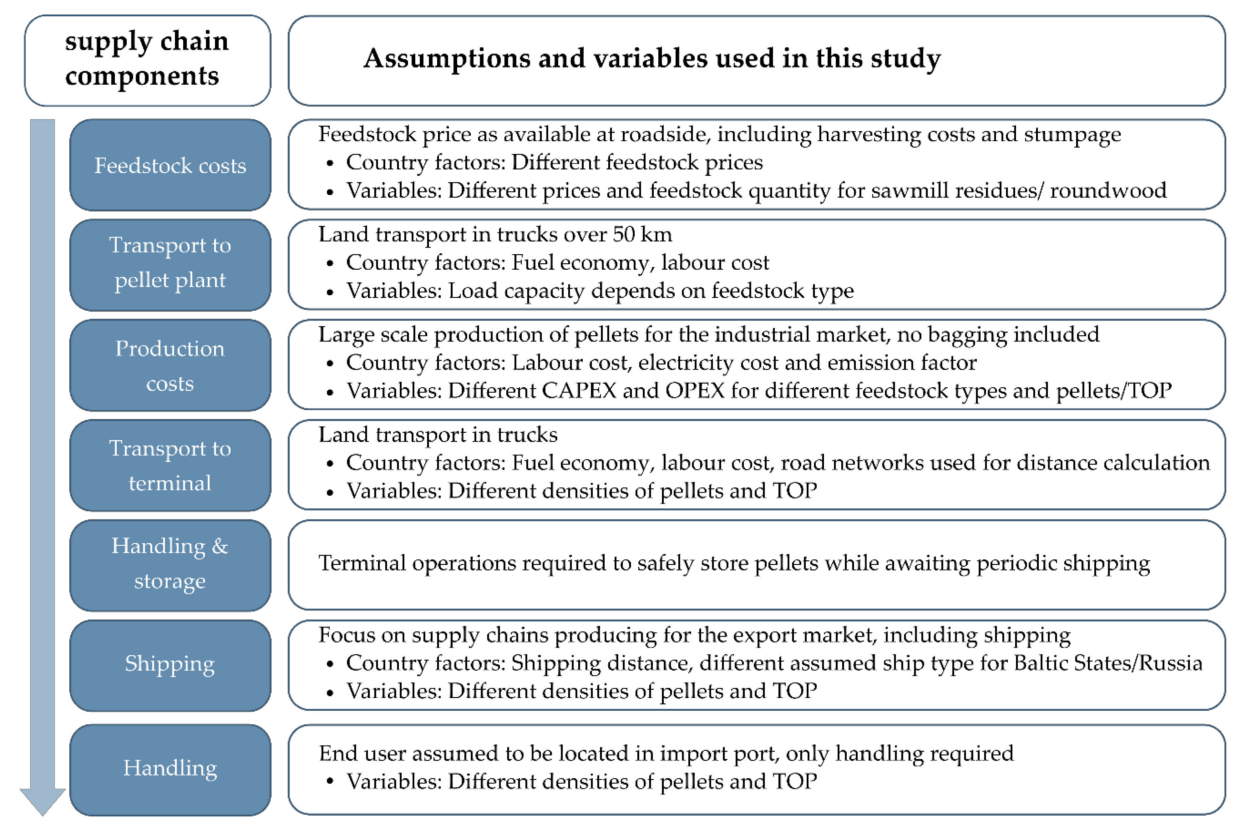

Figure 2. Typical wood pellet supply chain, including the country factors varied in this study as well as the impact of two different variables, the choice of feedstock between sawmill residues or roundwood and the choice of pelletization technology between pellets or torrefied pellets (TOP).

For the calculation within cost limits, a few criteria were included. A limit of $150 € / t$ pellets CIF ARA (costs, insurance and freight at the Amsterdam-Rotterdam-Antwerp ports), was used as reference, based on contract prices of pellets from Canada and the US fluctuating around this price level between 2012-2017 [21]. As a lower limit, total costs of $125 € / t$ pellets were assumed, reflective of a situation in which there are fewer subsidy schemes supporting the use of wood pellets, and prices need to be more competitive. On the other end of the spectrum, cost limits of 175 and $200 € / t$ pellets were used. These higher costs represent scenarios in which the use of wood pellets is increasingly subsidized, or in which the use of fossil fuels has become considerably more expensive. The maximum costs for torrefied pellets were assumed to be equal to regular wood pellets on an energy basis, and therefore $114 \%$ higher per tonne of pellets. Shipping costs and emissions were calculated to the Port of Rotterdam and are considered representative for the entire Amsterdam-Rotterdam-Antwerp (ARA) region. The expected price difference between all ports in western Europe is very small based on the small difference in shipping distance. Therefore, these results can also be considered a very close representative for other import regions in for instance the UK, Belgium or Denmark.

Supply chain components included in the cost and emission analyses can be seen in Figure 2. For each component, assumptions were made on the specific supply chain design, as explained in Section 2.1. These design choices impact the total costs and emissions and therefore have an impact on 
total calculated production potentials as well. For certain components, such as shipping, costs vary only with the type of ship used and the shipping distance. For other components, country differences were included, for instance in the form of differences in fuel, electricity and labour costs.

\subsection{Supply Chain Costs and Emissions}

The RED II GHG calculation methodology for biofuels prescribes that total emissions need to be calculated as the sum of emissions from raw material extraction/cultivation, emissions from processing, transport and distribution, emissions from fuel combustion and annualized emissions from carbon stock changes, minus emission savings from carbon storage through improved forest management and $\mathrm{CO}_{2}$ capture and geological storage or replacement [1]. This methodology was applied to the calculation of emissions in this research, with the exception of both positive and negative carbon stock changes caused by land-use change or improved management. Whereas changes in carbon stock can add significantly to total emission savings or losses, it could not be assessed within the limited scope of this paper. Production of energy from biofuels was not assumed to be combined with carbon storage or replacement, since this technology is currently not widely used and is not considered an available option for most bio-based power plants. This yields the following Equation (1) for total emissions (E), adapted from the RED II methodology [1]:

$$
\mathrm{E}=\mathrm{e}_{\mathrm{ec}}+\mathrm{e}_{\mathrm{p}}+\mathrm{e}_{\mathrm{td}}+\mathrm{e}_{\mathrm{c}}
$$

where $\left(e_{e c}\right)$ is the emissions from extraction or cultivation of raw materials, in this case forestry residues, $\left(\mathrm{e}_{\mathrm{p}}\right)$ are the processing emissions from the production of pellets, emissions from transport and distribution $\left(e_{t d}\right)$ is a combination of the transport of raw material and transport of pellets in the production country and internationally, until delivery at energy companies located in the Port of Rotterdam. This category also includes loading and unloading at the various supply chain locations. Following RED II methodology, emissions from combustion of biomass to fuel processes $\left(\mathrm{e}_{\mathrm{c}}\right)$ only includes non- $\mathrm{CO}_{2} \mathrm{GHG}$. The emission factors for pellets of $\mathrm{CH}_{4}$ and $\mathrm{N}_{2} \mathrm{O}$ were taken from [22], and were converted to $\mathrm{CO}_{2 \text {-eq }}$ by using the global warming potential values for a 100-year time horizon from the Intergovernmental Panel on Climate Change (IPCC) Fifth Assessment Report [23].

Savings (S) were calculated compared to RED II fossil fuel comparators for electricity $\left(\mathrm{F}_{\mathrm{el}}\right)$ and heat $\left(\mathrm{F}_{\mathrm{h}}\right)$ of respectively 183 and $80 \mathrm{gCO}_{2 \text {-eq }} / \mathrm{MJ}_{\mathrm{th}}$. Efficiencies of energy production were assumed to be $40 \%$ for electricity and $89 \%$ for heat, based on pellet-based electricity or heat production, following Equation (2) [1,24].

$$
\mathrm{S}=\frac{\mathrm{F}_{(\mathrm{el} / \mathrm{h})}-\mathrm{E}}{\mathrm{F}_{(\mathrm{el} / \mathrm{h})}}
$$

\subsubsection{Market Prices and Costs}

There is a difference between supply chain costs and prices, depending on whether profit margins are included for the different components. In this research, wherever possible, calculations were based on costs, excluding profit margins for supply chain actors. This was considered to yield more robust results since profit margins can vary significantly between different supply chain actors and will vary over time as a response to market dynamics. An exception to this is the costs of feedstock. Calculating the biomass costs based on stumpage fees and harvesting and collection costs was not feasible for all countries since data on these components is lacking. Therefore, the choice was made to use biomass prices available at roadside instead of biomass costs to achieve homogeneous results across all regions. In the remainder of this article, the term cost will be used for all supply chain components, in the case of feedstock this refers to the biomass prices paid by pellet producers. The development of feedstock prices is uncertain and depends on many factors such as demand developments, competition for feedstock, improvements in infrastructure or technological innovations and productivity of forest areas. Especially in new markets, without large pellet sectors, the impact of increased feedstock demand 
for pellet production on feedstock prices is uncertain. Potential market developments and changes in feedstock prices lie beyond the scope of this article and could not be assessed. The assumption was made that current costs of feedstock are stable and will remain constant when demand increases.

\subsubsection{Extraction and Cultivation}

The different forestry feedstocks modelled are pulpwood, logging residues and sawmill residues, with assumed moisture contents of $50 \%$ for pulpwood, $55 \%$ for logging residues and $30 \%$ for sawmill residues [25]. Pulpwood is defined, following the definitions used by the U.S. Forest Service, as wood that does not meet the quality standards for sawlogs, including a diameter at breast height over $23 \mathrm{~cm}$ for softwood and over $28 \mathrm{~cm}$ for hardwood, but does contain a minimum of $50 \%$ sound wood fiber by volume [26,27]. Definitions of pulplogs and sawlogs could be different in other countries. Country specific data on prices of pulplogs, as will be discussed in Section 2.1.3, were used as such, without adjusting for differences in definitions. In case data was available for different diameter classes, the specific diameter class assumed will be specified. The volume of a tree meeting sawlog standards furthermore only includes the part of the trunk from a 1-foot stump to a $15 \mathrm{~cm}$ diameter top (softwood) or $20 \mathrm{~cm}$ diameter top (hardwood) [27]. A felled tree can therefore yield sawlog as well as pulplog timber, with tops and branches being classified as logging residues. Pulplogs are too small and of too low quality to be used by sawmills but can be used by other forest product industries such as pulp and paper companies and pellet mills. Logging residues are generated during harvesting activities and consist of damaged or degraded trees that cannot be utilized by industries requiring premium timber, as well as tops and branches of harvested trees. Sawmill residues consist of residues generated during sawtimber production processes that are available for use by other industries. This consists of a mixture of sawdust, shavings and chips. Per RED II prescribed methodology, feedstock supply emissions are only allocated to pulpwood and not to residues. Allocation was done on mass basis for reasons of simplicity, instead of energy basis which would be more realistic [28]. See Table 1 for fuel input during forestry management. This data is based on medium productive forest plantations. Not all forestry production in the included countries will be based on cultivated forestry feedstock, and while this study excludes biomass from primary forests, other types of forests, such as natural or semi-natural forests are included in accordance with RED II methodology [1]. Still this data is considered a good assumption since pellet production is facing relatively strict sustainability criteria, favouring the use of feedstocks from forestry plantations as opposed to feedstock from more natural forests. Furthermore, an increase in feedstock demand for pellet production is expected to result in increased management of forests [29].

Table 1. Assumptions on forestry management and required fuel and fertilizer inputs, adapted from [29]. Forestry plantation management was assumed to include mid-rotation thinning, chemical and mechanical site preparation and some application of fertilizers during growth [29]. Fuel emissions are based on mobile diesel consumption [30].

\begin{tabular}{|c|c|c|}
\hline Activity & Quantity & Unit \\
\hline Raking and spot piling (diesel fuel) & 43 & $\mathrm{~L} / \mathrm{ha}$ \\
\hline Bedding (diesel fuel) & 53 & $\mathrm{~L} / \mathrm{ha}$ \\
\hline Planting (diesel fuel) & 28 & $\mathrm{~L} / \mathrm{ha}$ \\
\hline Fertilization (DAP) & 224 & $\mathrm{~L} / \mathrm{ha}$ \\
\hline Fertilizer application (heli fuel) & 9 & L/ha \\
\hline Thinning (diesel fuel) & 616 & L/ha \\
\hline Fertilizer use (urea) & 358 & $\mathrm{~L} / \mathrm{ha}$ \\
\hline Aerial fertilizer application (jet fuel) & 9 & $\mathrm{~L} / \mathrm{ha}$ \\
\hline Clear-cut harvest (diesel fuel) & 616 & L/ha \\
\hline Residue collection (diesel fuel) ${ }^{1}$ & 2.2 & $\mathrm{~L} / \mathrm{t}$ residues \\
\hline Pulpwood yield thinnings ${ }^{2}$ & 40 & $\mathrm{~T}_{\text {o.d. }} / \mathrm{ha}$ \\
\hline Pulpwood yield clear-cut & 100 & $\mathrm{~T}_{\text {o.d. }} /$ ha \\
\hline Yield total & 140 & $\mathrm{~T}_{\text {o.d. }} /$ ha \\
\hline
\end{tabular}

${ }^{1}$ Based on Lindholm et al. [31]; ${ }^{2}$ Assuming every third row is removed by thinning and thinning results in $50 \%$ enhanced growth $[29,32]$. 


\subsubsection{Feedstock Price}

The costs of harvesting were not explicitly calculated, since prices for biomass were reported on the basis of roadside costs, including the costs for forestry management, harvesting and collection. This study relies largely on country specific prices of forestry fibers, thereby not considering regional differences. An exception is made for the US where a distinction was made between the Southeast (SE) and Northeast (NE), and Canada where a distinction was made between the Southeast and Southwest (SW). The United States Energy Information Agency (US EIA) publishes monthly data on the average feedstock prices paid by pellet producers [32]. This is considered a good approximation to use for the Southeast, since pellet capacity in the US SE makes up $70 \%$ of the capacity in the entire country. The average price of 2018 was used, calculated from monthly data on average prices and production quantities. US EIA data is given for different feedstock types, among which roundwood/pulpwood and sawmill residuals. There is no significant difference in prices between the different feedstock types reported by the US EIA [32]. Therefore, the assumption was made that prices for raw material are equal for all feedstock types in the US SE, at least on a wet basis.

Prices in Canada, US and Brazil were calculated relative to the US EIA data. Forest2Market reported on prices of hardwood and softwood in Brazil, the SE US and NE US and SE Canada and SW Canada in 2017 [33]. From this data, an average value of softwood and hardwood prices was calculated for these regions. This value was converted to the level of US EIA feedstock prices using the ratio between the US EIA and Forest2Market prices for the SE US. Feedstock prices in the Baltic States and Russia were taken from a variety of sources. Data was available for pulplogs or sawlogs, sometimes of specific specified species and tree size categories. Feedstock prices in Estonia were based on pulpwood biomass from state forests and were first averaged for softwood and hardwood species using data on the distribution of fellings [34]. Latvian data, for the second quarter of 2018, taken from the central statistics bureau, distinguished between different species and diameters. Softwood prices are $65-95 \%$ higher than hardwood prices and are reported in different size categories. Considering this large price difference, the assumption was made that in the case of Latvia pellet production would be based on the more affordable hardwood species. Pulplog prices were based on average costs of hardwood trees $<24 \mathrm{~cm}$ diameter. Lithuanian data was given as the average price of pulpwood sold from state forests in 2018, per cubic meter [35]. Russian feedstock prices were based on price data for pulpwood, averaged for softwood and hardwood species [36]. For the various countries, data on residue prices could not be found. Therefore, just as in the US case, prices of harvest and sawmill residues were assumed equal to the price of pulpwood, at roadside or the mill gate where residues are produced, on a wet basis.

\subsubsection{Processing}

In the case of pulpwood use, pelletization of forest biomass starts with debarking, and course grinding to obtain similar particle size. All feedstock types then require drying and fine grinding in a hammer mill, pelletization, cooling and storage [37]. Cultivation and transport emissions of feedstock consumed for drying purposes were allocated to pelletizing emissions. Energy consumption for the different pelletizing components was taken from several literature studies, with the average of multiple values being used [38-44]. During pelletization, a loss of $1 \%$ feedstock was assumed. The produced pellets were assumed to have an energy content of $17.5 \mathrm{GJ} / \mathrm{t}$ and bulk density of $0.65 \mathrm{~m}^{3} / \mathrm{t}$. For the generation of electricity and heat, pellet mills were assumed to generate heat in a boiler fuelled with biomass, assuming an efficiency of $85 \%$, with the additional use of grid electricity [20]. All assumptions on energy requirements and efficiencies are included in Table A6 of Appendix B.

Pelletizing costs are difficult to determine, as discussed in [37]. Using the data laid out in this article, three different values were assumed for pelletizing costs, the median value of costs from literature was used as the baseline, medium cost value. The first and third quartile values were used as a low and high scenario for the calculation of pellet production potentials. Part of the variation of literature costs can be explained by supply chain design differences. In this study, a distinction 
was made between capital costs, maintenance costs, labour costs and costs for electricity and heat production. Capital costs are kept constant for all feedstock types, with the exception of costs for grinding equipment, which is not required when using sawmill residues. It must be noted that in practice many pellet mills will use a mixture of feedstock types and will therefore also require grinding equipment. The option of exclusively sawmill residues-based pellet production is however considered feasible in case of close proximity to and collaboration with lumber mills. For this reason, this study includes a cost analysis of pellet production based only on sawmill residues, using some adapted cost factors as explained in this section. Maintenance costs are assumed to be constant for all feedstock types and sizes, and were based on Pirraglia et al. [44]. The base labour costs were based on the United States. Costs in other country were calculated by applying a cost factor based on hourly wages compared to the US, as given in Appendix A. Labour requirements and costs were assumed to be equal for all feedstock types.

Emissions of torrefied pellets were calculated using the same assumptions and data as for wood pellets. During torrefaction, biomass is heated to $200-300{ }^{\circ} \mathrm{C}$ in the absence of oxygen, resulting in the devolatization of hemicellulose and cellulose $[45,46]$. Pellets from torrefied material have improved characteristics such as a higher energy and bulk density, $20 \mathrm{GJ} / \mathrm{t}$ and $0.75 \mathrm{~m}^{3} / \mathrm{t}$ respectively, increased brittleness and improved hydrophobicity. During the torrefaction process, roughly $30 \%$ of the input mass is turned into several volatile components [46]. The torrefaction gas emitted through this process can be combusted to provide the heat required for the torrefaction process as well as drying of the biomass prior to torrefaction. Total processing heat demand and the heat supply generated by the combustion of torrefaction gas was calculated based on Mobini et al. [42]. The main cost and emission factors of pellet production used in this study can be found in Table 2.

Table 2. Base costs factors of CAPEX and OPEX costs for the United States, in $€ / \mathrm{t}$ pellets, for a $500 \mathrm{kt} / \mathrm{y}$ pellet plant, based on data from [37].

\begin{tabular}{cccccc}
\hline Component & Pellet Type & Unit & Pulpwood & Logging Residues & Sawmill Residues \\
\hline CAPEX & WP & $€ /$ t pellets & 7.9 & 7.9 & 6.1 \\
& TOP & $€ / \mathrm{t}$ pellets & 10.2 & 10.2 & 9.3 \\
Maintenance & WP/TOP & $€ / \mathrm{t}$ pellets & 5.0 & 5.0 & 5.0 \\
Labour & WP/TOP & $€ / \mathrm{t}$ pellets & 7.4 & 7.4 & 7.4 \\
Electricity & WP & $\mathrm{kWh} / \mathrm{t}$ pellets & 183 & 163 & 163 \\
& TOP & $\mathrm{kWh} / \mathrm{t}$ pellets & 189 & 169 & 169 \\
Heat & WP & $\mathrm{kWh} / \mathrm{t}$ pellets & 1080 & 1333 & 429 \\
& TOP & $\mathrm{kWh} / \mathrm{t}$ pellets & 1764 & 2093 & 917 \\
\hline
\end{tabular}

\subsubsection{Transport and Distribution}

Feedstock is assumed to be transported by truck to pellet plants. Weight limits vary for different feedstock types, as can be seen in Table 3. Fuel consumption was based on a load of 26 tonne/truck, which was adapted to other weight limits, based on an assumed linear relation between weight and fuel consumption [47]. Costs were calculated using different diesel prices, of May 2019, in the respective countries. Road transport includes costs for labour, against country specific labour prices. Fuel and labour costs for the different countries included in this study are given in Appendix A. To any trip, 50\% of the total duration was added for loading/unloading, driver breaks and delays. Trucks were assumed to work at $100 \%$ capacity for the trip from forests to pellet plants. Transported feedstock was assumed to contain some contaminants in the form of sand or metals, measuring up to $3 \%$ of the total mass.

For transport of pellets, both road and rail transport were considered viable theoretical options. Road transport is calculated in the same way as feedstock transport but based on an assumed load limit of $25 \mathrm{t} /$ truck [22], using heavy diesel trains. Since separate data on fuel consumption was available for the United States, Canada and the EU, the distinction was made between these geographical regions. For all other regions, the emissions of the United States were assumed. Costs of rail transport were based on a fixed price and a distance dependent price of the railway company CSX Transportation 
(CSXT) in the United States, as given in Gonzales et al. [48]. Return trips on both road and rail are assumed to be empty, with emissions and costs being fully allocated to feedstock transport based on the empty weight of trucks and rail cars [30]. Detailed information on transport cost calculations can be found in Visser et al. [37]. General cost calculations to compare the different countries were based on a feedstock transport distance of $50 \mathrm{~km}$ and a transport distance from pellet plants to export ports of $500 \mathrm{~km}$, via road transport.

Table 3. Data used for calculation of costs and emissions of truck transport of forestry feedstock.

\begin{tabular}{cccc}
\hline Activity & Quantity & Unit & Source \\
\hline Load limit road & & & \\
Weight load limit - pulpwood/thinnings & 26.0 & $\mathrm{t} / \mathrm{ruck}$ & {$[49,50]$} \\
Weight load limit - chips & 28.5 & $\mathrm{t} / \mathrm{truck}$ & {$[51]$} \\
Volume load limit - sawdust & 19.7 & $\mathrm{t} / \mathrm{truck}$ & {$[51]$} \\
Weight load limit - pellets & 25.0 & $\mathrm{t} / \mathrm{truck}$ & {$[22]$} \\
Fuel consumption road (diesel) & & $\mathrm{L} / \mathrm{km}$ & {$[47]$} \\
Pulpwood/thinnings/pellets & 0.45 & $\mathrm{~L} / \mathrm{km}$ & {$[47]$} \\
Chips & 0.47 & $\mathrm{~L} / \mathrm{km}$ & {$[47]$} \\
Sawdust & 0.41 & $\mathrm{~L} / \mathrm{km}$ & {$[47]$} \\
Empty truck & 0.28 & $\mathrm{t} / \mathrm{trip}$ & {$[52]$} \\
Load limit rail & & & \\
Payload & 1820 & $\mathrm{~L} / \mathrm{km}$ & {$[30]$} \\
United States & & $\mathrm{L} / \mathrm{km}$ & {$[30]$} \\
Canada & 12.1 & $\mathrm{~L} / \mathrm{km}$ & {$[30]$} \\
EU (heavy) & 11.1 & &
\end{tabular}

\subsubsection{Shipping and Port Operations}

Shipping fuel consumption was calculated as in Visser et al. [37], largely following the methodology as given in [22]. Fuel consumption and emissions were calculated for four different ship types: short sea ship (SSS), Handysize, Handymax and Supramax. Fuel consumption was taken from the International Maritime Organisation and shipping distances between two ports were taken from online calculation tools $[53,54]$. Pellet transport from the Baltic countries and Russia was assumed to be done in an SSS vessel with a deadweight capacity of $10 \mathrm{kt}$. The other ports were assumed to be able to utilize the three larger ship types, which were varied in different scenarios, with a Handymax ship used as the reference case. Shipping costs were calculated using data on fuel costs and charter costs, both of which fluctuate over time and are therefore uncertain. Both fuel costs and charter costs were varied in a low, medium and high option, as can be seen in Table A5.

Emissions from engine use during berth, anchorage and manoeuvring operations were included during the period of loading and unloading, and vary per ship size [55]. The maximum unloading capacity was based on the Port of Rotterdam, and was set at 10,000 t/day [54]. This unloading rate does not include potential delays caused by bad weather or scheduling difficulties. The assumption was made that loading emissions equal the unloading emissions. Additional terminal operations were also included, including the emissions from ship unloading and conveying of pellets [56]. These operations are based on the Rotterdam terminal as well, assuming pneumatic ship unloading and conveying across $1500 \mathrm{~m}$ [54]. Costs of port operations were based on the above methodology, calculated using country specific costs of electricity. Labour costs were left out of this equation since these depend largely on the degree of automation and form a small part of total costs compared to, for instance the daily charter costs. 


\subsection{Techno-Economic and GHG Supply Potential}

\subsubsection{Feedstock Availability}

The impact of maximum supply areas was calculated by totalling the feedstock availability within supply areas in the different export countries. The availability of mill residues was excluded since this availability is inherently limited by the existence and proximity of other industries, and reliable spatial data on the extent of timber and paper industries in all included countries was not available. Logging residues were also excluded from total availability. Although this source of feedstock could be utilized for pellet production, mobilizing these residues requires significant effort and is usually not cost efficient compared to pulpwood [57]. Increased use of logging residues instead of pulpwood presumably requires the existence of specific policies or support schemes. Furthermore, the extent of logging residue availability depends on the type and size of trees as well as the minimum merchantable diameters specified locally, and is therefore difficult to estimate spatially explicit [58]. The total potentials calculated in this study can be considered indicative of the differences between various production regions but are not considered to represent accurate estimates of pellet production potential. The potential availability of forestry feedstock was analysed spatially explicit, based on raster maps of forested areas in the different countries. Detailed information on the data used for all different countries can be found in Appendix C. All data given in volume was converted to weight based on a value of $990 \mathrm{~kg} / \mathrm{m}^{3}$ green wood, taken from [59], calculated as the average between softwood and hardwood at 50\% moisture content (MC) on a wet basis. Per tonne of pellets, 2.1 tonne of pulpwood feedstock is required. Calculated using the MC of $50 \%$ and a MC of dried feedstock of $8 \%$, an efficiency of heat production of $85 \%$ and heat requirement for drying of $1200 \mathrm{kWh} / \mathrm{t}$ of evaporated water $[38,40]$.

\subsubsection{Sustainability Restrictions}

To ensure that use of bioenergy results in carbon savings, the total forestry stock should not decrease, as required in the RED II. For this reason, total availability of forestry resources in this study was based on current annual incremental growth as opposed to total growing stock. Annual growth varies per tree and forest type, forest management intensity, climate and other factors. Whereas spatial data on annual growth was available for some countries, for other countries estimates had to be made on available data and additional literature. Appendix $C$ shows the method used in the different countries to calculate feedstock availability. This includes additional sustainability criteria such as the protection of land with high biodiversity value. Although it was not considered feasible to do a detailed analysis of biodiversity and species richness, this concern was included through the exclusion of untouched forest areas and areas marked as protected areas from total forest areas. In the case of Brazil also areas inhabited by indigenous people were excluded. In the case of the Baltic States, availability was taken from wood production maps, as analysed by the European Forest Institute. These maps already include several locational factors such as protected areas, and the resulting maps were used as such $[60,61]$. To avoid distortion of local markets and displacement of emissions, pellet production should not use feedstock already used locally for production of other forest products [61]. The existing demand for forestry feedstock could not be assessed sufficiently detailed for the different countries. Instead a fixed percentage of incremental growth was assumed to be available for pellet production. In the US SE, in 2014, forest harvest removals for pellet production represented $<3 \%$ of removals in the entire region [62]. Since then, pellet production in the SE US has doubled roughly, resulting undoubtedly in more removals. As upper limit in this study a value of $10 \%$ of the total annual increment was assumed. This forestry feedstock availability was assumed to be in the form of pulplogs, excluding harvest residues such as tops and branches. The collection and processing of residues requires several additional processing steps, necessitating the development of new procedures while the biomass is of relatively low energetic and monetary value. For this reason, the assumption was made that pellets will be produced from pulpwood and not from harvest residues. Other factors, 
such as the amount of biomass that needs to remain in forest areas to satisfy biodiversity and soil quality standards were not included [17].

\subsubsection{Mobilization}

Pellets can only be produced and exported cost efficiently if feedstock can be transported across roads and is located close enough to export ports. To analyse this, the availability was calculated in relation to distance from the main export ports, in $100 \mathrm{~km}$ tranches based on the use of road networks, until a maximum of $2000 \mathrm{~km}$. Distances from export ports that exceeded $100 \mathrm{~km}$ were assumed to be covered by transport of pellets and not feedstock. Transport distances were calculated based on Railroads maps and OpenStreetMap, as made available by Esri [63] and Geofabrik [64]. Assumed speed limits were varied for motorways $(80 \mathrm{~km} / \mathrm{h})$, primary and secondary roads $(60 \mathrm{~km} / \mathrm{h})$ and tertiary and residential roads $(40 \mathrm{~km} / \mathrm{h})$. In the Baltic states even smaller, unpaved roads were included $(20 \mathrm{~km} / \mathrm{h})$, unlocking additional forested areas. In the case of the US, where road networks are very extensive, all roads smaller than secondary roads were excluded. Transport across road with an assumed speed limit $<80 \mathrm{~km} / \mathrm{h}$ was factored according to the additional costs per distance, depending on the balance between fixed and variable costs. Service areas were calculated in ArcGIS using the Network Analyst Service Area tool (ArcGIS 10.7, Esri, Redlands, CA, USA). In calculating the availability within limits of maximum costs and GHG emissions, the maximum distance of each service area was used, e.g., the costs of pellets from a service area between 0-100 km were calculated using $100 \mathrm{~km}$ as transport distance value. In case of overlapping service areas, as is the case with several export ports in close proximity, the potentials were allocated based on lowest costs and emissions to a single export port. Figure 3 shows an example of the exclusion of forested areas based on biodiversity concerns or transport distance to export ports in Brazil.

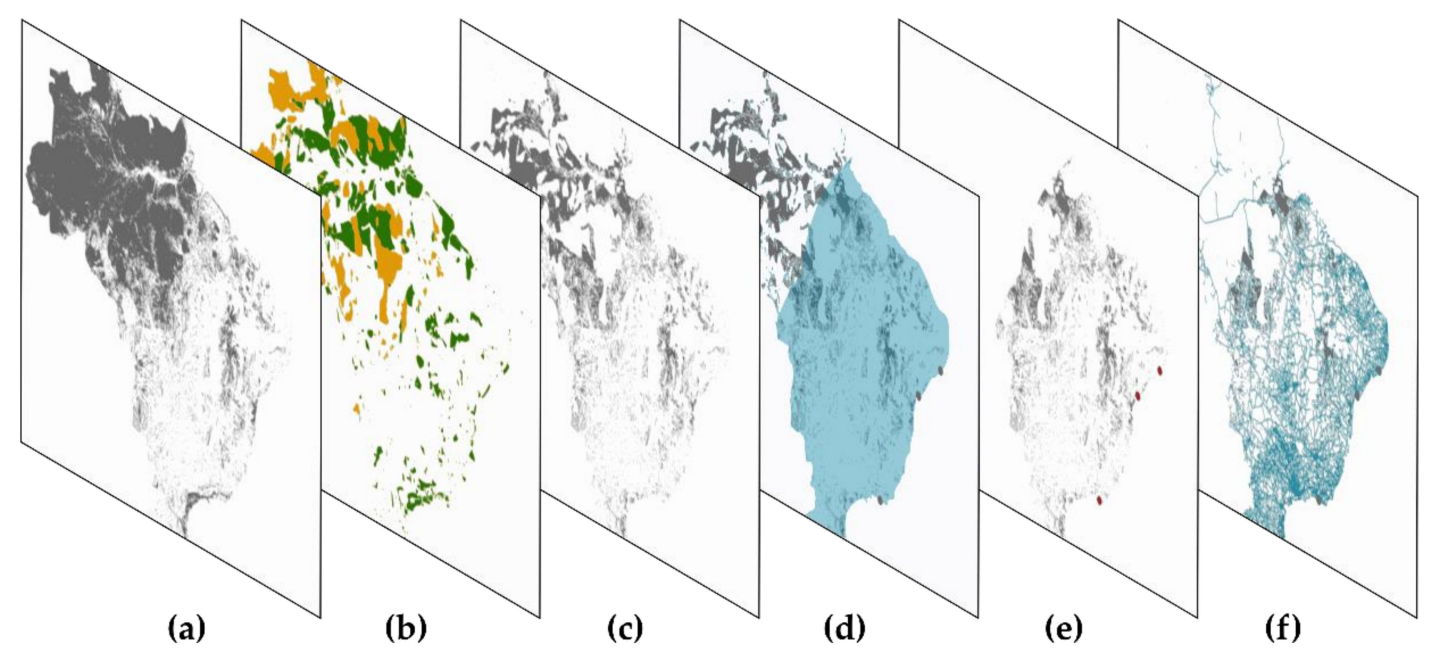

Figure 3. (a) Example of forestry feedstock availability calculation for Brazil, based on total area classified as forest vegetation by the Instituto Brasiliero de Geografia e Estatistica [65]; (b) Protected areas (green) and areas inhabited by indigenous people (orange), were based on data from [66-68]; (c) Forestry feedstock availability minus protected areas as shown in (b); (d) Only the areas within $2000 \mathrm{~km}$ from selected export ports were considered feasible for mobilization; (e) The resulting remaining potential areas for pellet production; (f) As the final step, OpenStreetMap road infrastructure, adapted from [64], was used to calculate transport costs.

\section{Results}

\subsection{Supply Chain GHG Emissions CIF ARA}

As shown in Figure 4, the largest component of total greenhouse gas emissions is pelletizing, although this depends strongly on the emission factor of electricity production in the different countries. 
Pelletizing emissions constitute $16 \%$ of total emissions for pellets produced in Brazil, compared to $54 \%$ in the case of Latvia. Emissions of silviculture and harvest and feedstock transport are also significant, contributing a combined $26-60 \%$ of total emissions. Shipping emissions vary with transport distance and are almost a factor 5 higher for western Canada than for Lithuania. In all countries, emissions of torrefied pellets are lower than emissions of pellets, the difference between the two increases with increasing transport emissions. Supply chain emissions for pellets from pulpwood are $46-91 \%$ higher than emissions for sawmill pellets. This is largely the result of no allocation of silviculture and harvest emissions to sawmill residues, which is in line with the RED II methodology followed in this article [1]. Furthermore, the emissions of feedstock transport and pelletizing are lower because of the lower moisture content of sawmill residues compared to pulpwood. Supply chain emissions of TOP are consistently lower than wood pellets, including the pelletizing and torrefaction energy requirements. As a result of the combustion of torrefaction gas, energy requirements are lower per unit of energy delivered. The largest reduction was calculated to be for pellets from pulpwood, ranging between 12-24\% GHG savings. Results for TOP produced from sawmill residues, show a 210\% GHG saving. Calculations show that emissions for silviculture, harvest and feedstock transport are slightly higher for torrefied pellets, explained by the fact that the production of TOP requires more feedstock input. This is however more than compensated for by the fact that TOP have a larger energy density than WP, resulting in reduced transportation requirements per unit of energy delivered.

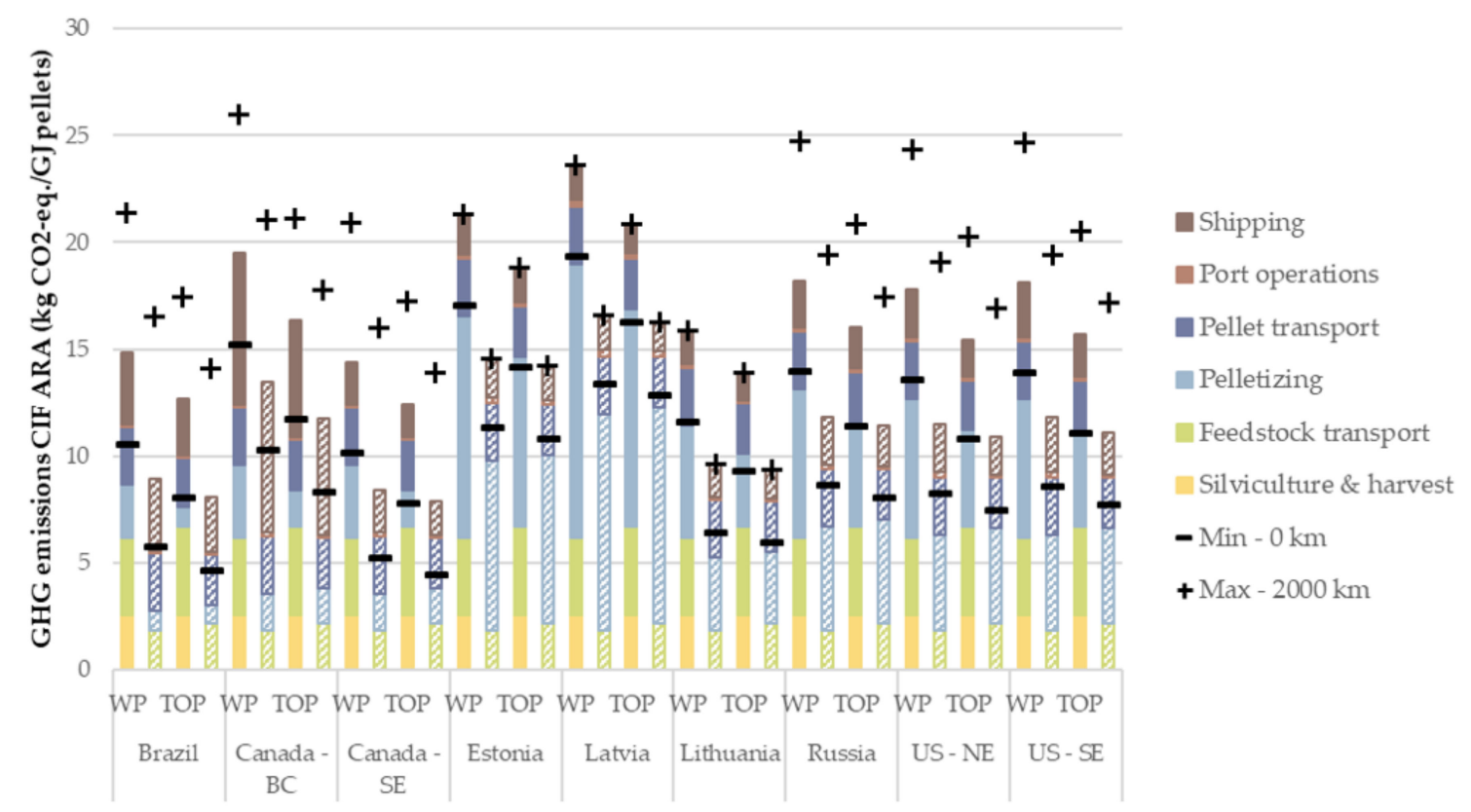

Figure 4. Supply chain greenhouse gas emissions for wood pellets and torrefied pellets made from pulpwood (solid) and sawmill residues (striped), for all analysed countries. Total emissions were based on feedstock transport distance of $50 \mathrm{~km}$ and pellet transport distance of $500 \mathrm{~km}$. As a sensitivity, minimum and maximum values are shown based on transport distance of pellets between 0-2000 km. Maximum transport distance in the Baltic States remains $500 \mathrm{~km}$, which is the maximum distance possible in these smaller countries. Shipping transport was calculated for Handymax ships, except for the Baltic States in which case the use of a short sea ship (SSS) was assumed.

\subsection{Supply Chain Costs CIF ARA}

The total costs of delivered pellets vary between $6.8 € / G J$ pellets for pellets from Brazil and $12.7 € / G J$ for pellets from Lithuania, shown in Figure 5. The largest share of pellet costs is the price of feedstock, contributing between $33-61 \%$ of total costs, which is the predominant cause for cost differences between the various countries. Transport costs also vary in the selected countries, most of all the shipping costs. Because of the different ship types assumed for the pellets transported across 
the Baltic Sea, costs for Latvia, Lithuania, Estonia and Russia are comparable to shipping costs from the other regions regardless of the much smaller transport distance. Supply chain costs of sawmill residue pellets, varying between 6.1-10.6€/GJ pellets, are consistently lower than that of pulpwood pellets, ranging between $2-27 \%$ cost savings. Costs of torrefied pellets are generally comparable or slightly higher on a mass basis, but lower on an energy basis. Per GJ of delivered pellets, torrefied pellets from pulpwood are up to 15\% cheaper, in the case of Russia. An exception to this is Brazil. High costs for electricity production cause significantly higher pelletizing costs for TOP, resulting in an $8 \%$ increase in total costs. Torrefied pellets made from sawmill residues are generally slightly more expensive than wood pellets. The lower feedstock drying requirements for sawmill residues reduce the benefit of combustion of torrefaction costs.

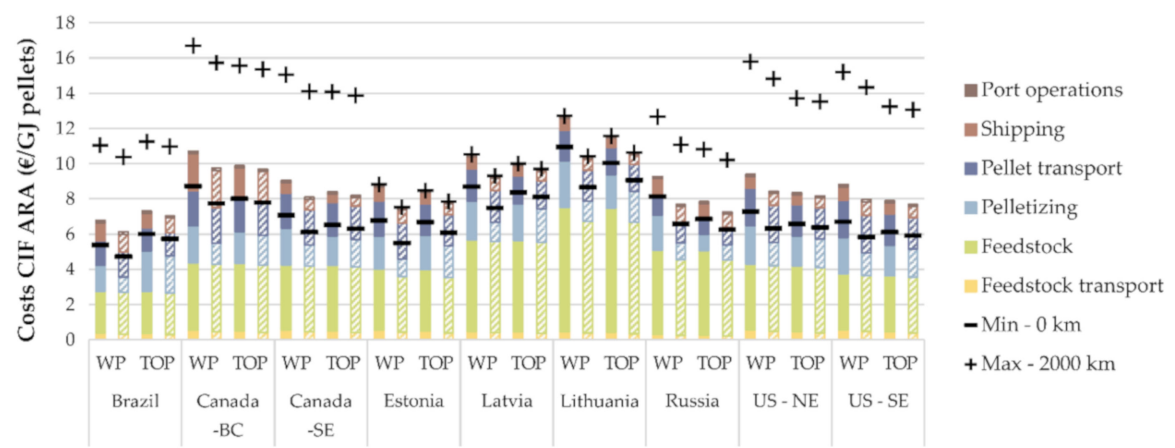

Figure 5. Supply chain costs for wood pellets and torrefied pellets made from pulpwood (solid) and sawmill residues (striped), for all analysed countries. Total costs were based on feedstock transport distance of $50 \mathrm{~km}$ and pellet transport distance of $500 \mathrm{~km}$. As a sensitivity, minimum and maximum values are shown based on transport distance of pellets between 0-2000 km. Maximum transport distance in the Baltic States remains $500 \mathrm{~km}$, which is the maximum distance possible in these smaller countries. Shipping transport was calculated for Handymax ships, except for the Baltic States in which case the use of a short sea ship was assumed.

\subsection{Combined Supply Curves}

Supply curves were generated based on the production potential of pellets in each region, sorted for lowest costs and combined in intervals of $2 \mathrm{Mt}$ production potential. The average costs and emission values for each interval was used to construct the line charts shown in Figure 6.

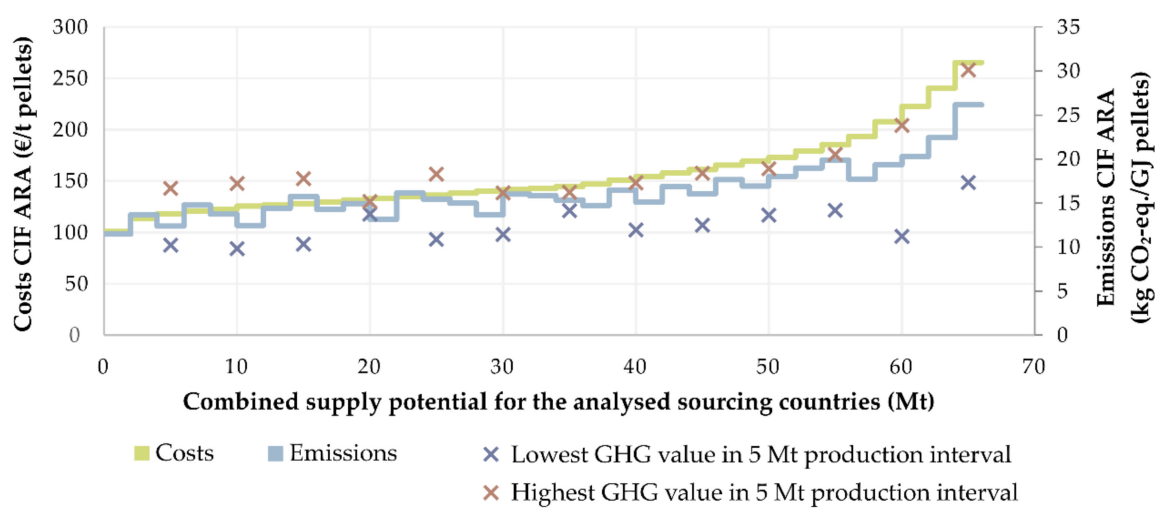

Figure 6. Cost supply curves of wood pellets made from pulpwood with corresponding GHG emissions. Assumed transport on road, across $50 \mathrm{~km}$ for feedstock. Shipping transport per Handymax, and SSS ship in the case of transport across the Baltic Sea-Sorted for lowest costs of wood pellets.

The lowest and highest GHG value within each $5 \mathrm{Mt}$ production potential intervals was also included to show the large variation within each range. There is a small correlation between costs and 
emissions. A defining factor in total emissions is the grid electricity emission factor. The countries in this study with affordable feedstock, Brazil, Canada, Estonia and the US, also have low emission factors. The most expensive part of the supply chain consists of pellets produced in regions far away from export ports and in regions with large shipping distances such as western Canada, resulting in increased costs as well as emissions. Still, the range of lowest and highest emissions is significant at most parts of the curve. Just optimizing for lowest costs could therefore result in suboptimal GHG emissions. The supply chain costs and greenhouse gas emission results for the different export regions, used to construct the combined supply curves as shown in Figure 6, are shown in more detail in Appendices D and E respectively.

\subsection{Maximum Supply Areas}

The differences in feedstock, pelletizing and shipping costs result in variations in the maximum transport distance across which feedstock and pellets can be transported while staying within the predetermined costs and emissions thresholds. In Figure 7, the difference between WP and TOP is shown, when assuming total maximum supply chain costs of $€ 150 / t \mathrm{WP}$, or the equivalent $€ 171 / \mathrm{t}$ TOP.

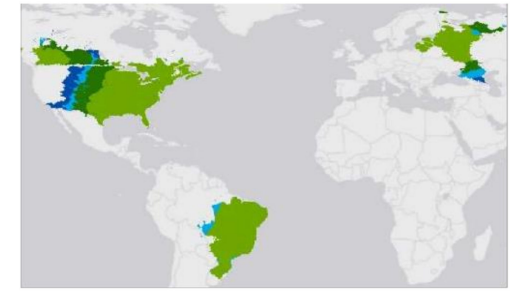

(a)

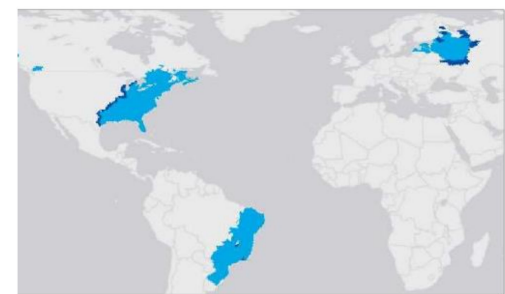

(c)

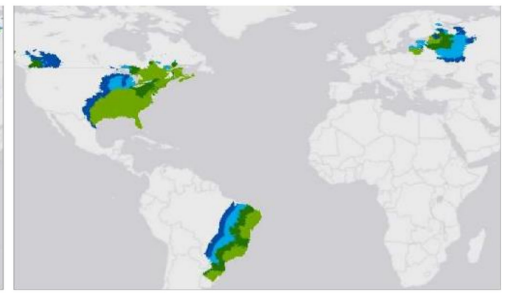

(b)

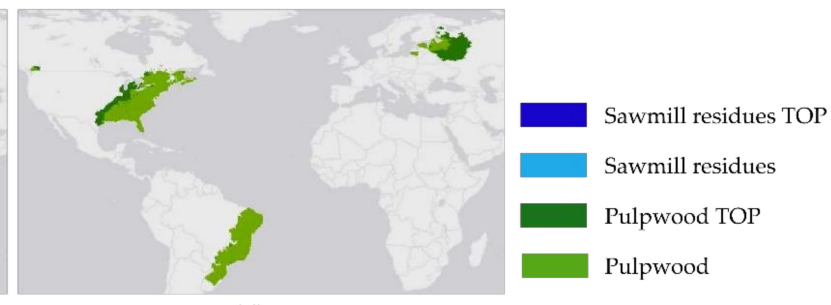

(d)

Figure 7. Maximum supply area of pellets made from sawmill residues and pulpwood when applying (a) GHG emissions savings; (b) 80\% GHG emission savings; (c,d) €150/t pellets CIF ARA for wood pellets, corresponding to $€ 171 \mathrm{t} /$ pellets CIF ARA for torrefied pellets, in proportion to the higher energy density.

This cost criterium excludes pellet production of WP made from pulpwood in Western Canada and large parts of Eastern Canada and the United States. The maximum supply area for sawmill residue pellets is larger, specifically in the case of WP for which a larger inland area of the SE US would be available for pellet production. A GHG emission reduction of $70 \%$ results in very large supply areas, in all countries, exceeding the $2000 \mathrm{~km}$ used as practical limitation for pellet transport. The reduction limit of $80 \%$ also results in relatively large potential supply areas compared to the cost limit of $€ 150 / t$ pellets. The difference between $70 \%$ and $80 \%$ is however already significant, impacting the maximum production areas in Brazil, SW Canada and Russia. When using pellet costs as a limiting factor, the difference between WP and TOP is relatively small in Brazil. This because the costs are dominated by other factors such as transport costs, and feedstock and pelletizing costs form a smaller part of the total supply chain costs than in other countries. In Latvia and Lithuania, high feedstock prices limit the production of regular and torrefied pellets from pulpwood in the entire country and only allow production in a small area when using sawmill residues. In Estonia, there is not much difference between the maximum supply area for the different feedstock and pellet types. In Russia, on the other hand, the difference between pellets produced from pulpwood and sawmill residues is large, pellets 
from sawmill residues can cost effectively be produced in a large part of Russia. GHG emissions in the Baltic states and Russia are much less of a limiting factor.

\subsection{Pellet Production Potential}

The potential production of pellets in the different countries is limited by the availability of feedstock as well as costs and emissions of pellet production and transport. Figure 8 shows the techno-economic pellet production potential of pellets made from roundwood in the different countries analysed. The potential as limited by supply chain costs, is largest in Brazil and the US. The least restricted scenario, the Low-cost scenario, at $200 € / t$ pellets gives a total potential of almost 60 million tonnes of pellets, of which $50 \%$ is sourced from Brazil and 39\% from the US. Total availability of forestry feedstock in the Baltic countries is small and prices of feedstock are high, resulting in a very low potential. Feedstock prices are more competitive in Canada and Russia. However, the main forestry potential in these regions is located more inland, at large transport distance from export regions, limiting the available feedstock for pelletization. The total potential from all countries is significantly impacted by supply chain costs limits. At the other end of the range, at an assumed cost limit of $125 € / t$ pellets, the total potential varies between 3-28 million tonnes in the different scenarios. Since the difference in costs between WP and TOP is very small, results are also very similar. Overall for TOP, the potential from Brazil is slightly lower and the potential from the US slightly higher. The total potential of torrefied pellet production and import falls within $95-103 \%$ of the wood pellet potential.

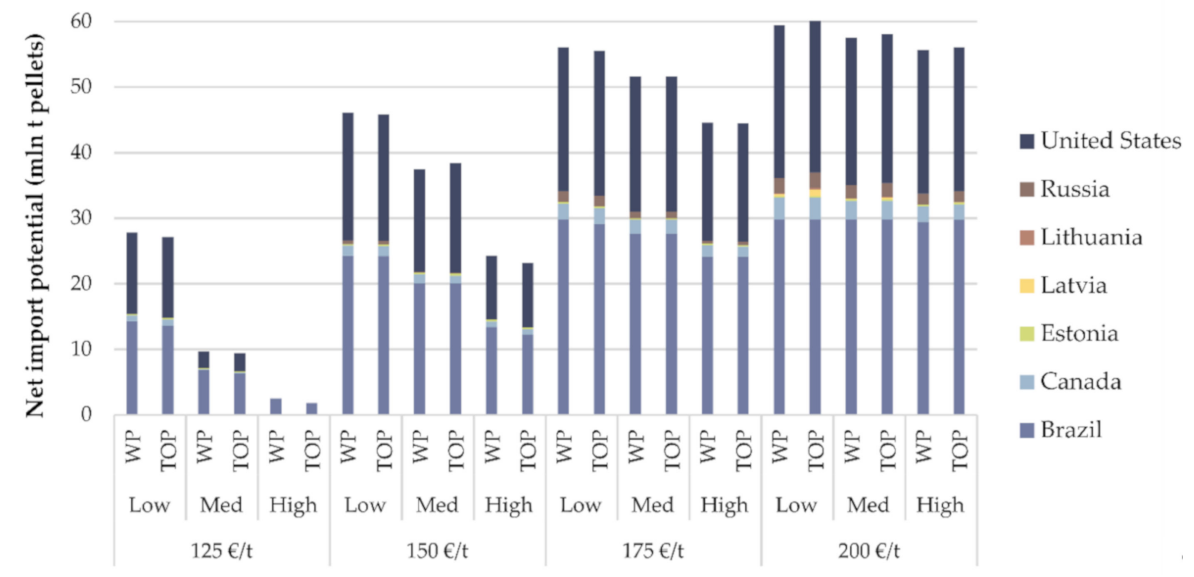

Figure 8. Techno-economic pellet production and net import potentials, CIF ARA, limited by supply chain costs-for wood pellets (WP) and torrefied pellets (TOP)-calculated using different assumptions on the development of pelletizing costs and shipping fuel and charter costs in a Low, Medium and High scenario.

The production potential limited by high GHG emission thresholds is lower, as can be seen in Figure 9 . At a $70 \%$ reduction target, almost the entire pellet production potential is available, $61 \mathrm{Mt}$ in the case of electricity production from pellets, of a maximum of $65 \mathrm{Mt}$. This reduction target does not form a limitation for pellets from Estonia, Latvia and Lithuania. The potential from these regions however remains small compared to the US and Brazil because of the lower availability of forestry feedstock. An 80\% reduction threshold reduces the total potential significantly from 61 to $16 \mathrm{Mt}$ pellets in the case of electricity production and $13 \mathrm{Mt}$ in the case of heat production. Going to the $85 \%$ threshold, the potential for electricity or heat production reduces to just $1 \mathrm{Mt}$ pellets. Especially in case of the $80 \%$ threshold, the production of torrefied pellets would increase the total potential significantly, with $23 \mathrm{Mt}$ pellets to almost $40 \mathrm{Mt}$ in the case of electricity production and $36 \mathrm{Mt}$ in the case of heat production. Especially in Brazil and the US, the production of torrefied pellets could allow for the import of larger amounts of pellets within the limits of certain GHG reduction standards. The potential availability of other feedstocks, such as harvest or industrial residues, was not considered 
in this analysis. This could significantly impact the production potentials, especially when limited by GHG emissions considering the relatively large reduction in supply chain emissions as shown in Figure 4. These potentials therefore do not represent an upper limit but should be viewed as an indication of the impact of stricter GHG thresholds.

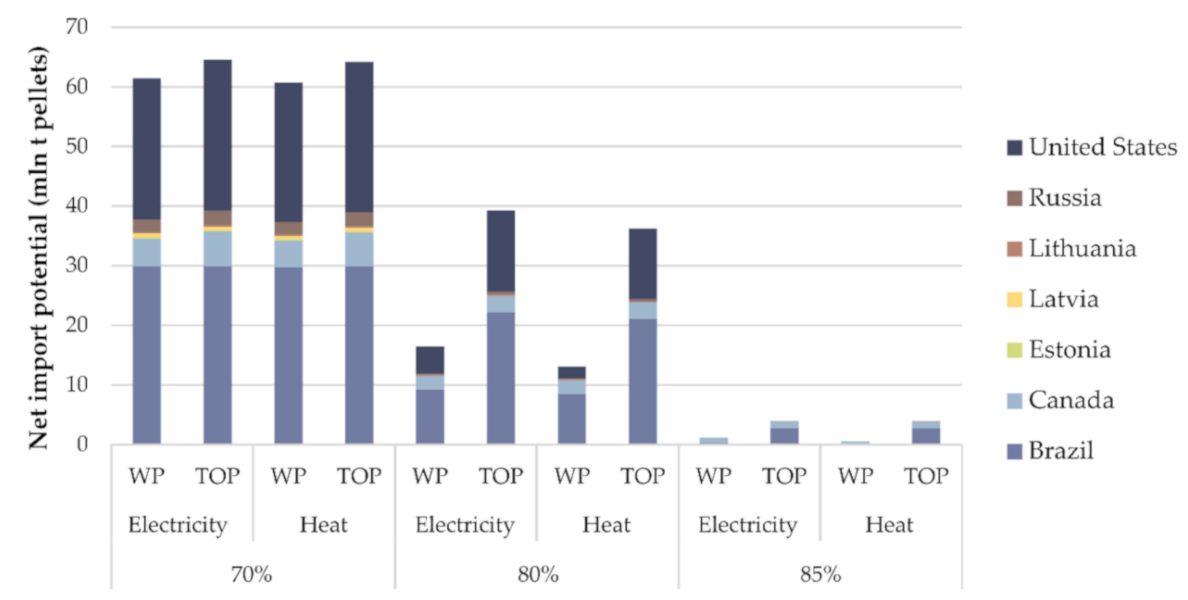

Figure 9. Techno-economic pellet production and net import potentials, CIF ARA, limited by supply chain GHG emissions-for wood pellets (WP) and torrefied pellets (TOP) produced from pulpwood.

\section{Discussion}

\subsection{Uncertainty Factors in Feedstock Availability}

Some of the supply areas analysed in this study might not be readily accessible due to natural barriers such as steep slopes or waterways. Furthermore, although some sustainability constraints such as supply chain emissions and forest stock were included, other limiting factors such as biodiversity or soil quality were not accounted for. Calculated potentials therefore do not reflect sustainable potentials but rather import potentials under a few selected (sustainability) criteria. The potential production totals calculated in this study were based on the availability of pulpwood in forests. This approach may have resulted in an underestimation of total feedstock availability since availability of industry residues, or residues from forestry operations such as tops and branches, was not included. In Latvia and Lithuania feedstock is relatively expensive and calculations in this study have shown that pellet production is only cost effective when using sawmill residues. At the same time, current pellet production in these countries is largely based on the use of sawmill residues, making up about $80 \%$ of the total feedstock consumption for pellets [6]. The calculated combined potential in Canada, Russia and the Baltic states is $6.9 \mathrm{Mt}$ in the GHG reduction scenario for torrefied pellets, the least strict criteria for these countries. Current production statistics show that the 2018 production in these countries combined also totalled $6.9 \mathrm{Mt}$ [6]. This is an indication that the estimation of potentials in this study is on the conservative side. The availability of sawmill residues is however inherently limited to the production capacity of wood processing industries. Solely relying on increased use of residues for growing pellet production is considered uncertain and risky.

The use of other feedstock types, such as agricultural residues, was not considered. In a country like Brazil it could be feasible to produce pellets from residues of sugarcane production, such as bagasse and straw. Research into alternative feedstocks can show whether there is potential for cost or emission reductions, and whether this would result in a significantly larger total production potential. Even without including agricultural residues, Brazil could become an important new supplier of pellets based on the low costs and emissions. Pellet production capacity in Brazil is currently very small. In 2018, total pellet production in Brazil totalled just $0.4 \mathrm{Mt}$ [6]. A potential limitation to feedstock availability in Brazil is the prominent and growing pulp and paper market in Brazil, which could pull available feedstock away from pellet production [69]. Local demand for other industries was assumed 
to be $90 \%$ of the incremental growth. If local demand, for instance for wood or paper products or local wood based generation of biofuels or bioenergy, exceeds this number, or even exceeds the incremental growth totals, there could be no pulpwood available for pellet production. Abt et al. [70] have modelled the impact of increased bioenergy production on softwood and hardwood removals, inventory and prices in Alabama, Florida and Georgia. Their results show that increased bioenergy consumption impacts the forestry sector, for instance resulting in an initial increase in prices of sawtimber. The impact on prices on the longer term, as well as the impact on forest area, inventory, removals and carbon stock strongly depends on the modelled supply and demand response as well as assumptions on utilization of logging residues and plantation growth increases. Kim et al. [71] have modelled impacts of global demand projections for bioenergy. Their results show that increased bioenergy demand will result in increased prices of pulpwood, while price changes of sawlogs are marginal. This work furthermore shows that overall levels of biomass, pulpwood and sawtimber harvesting will increase, achieved through a combination of timber substitution, increases in forest area and increases in forest management intensity. Especially the production of other wood-using industries, and the interaction with pellet mills, must be examined in more detail. The impact of competing demand on feedstock availability for pellets is twofold, a large existing wood and paper industry will likely result in lower availability of pulpwood but higher availability of logging and mill residues.

This study is not a full analysis of global feedstock availability, and other major pellet production regions, such as China and Vietnam, were not included [6]. On the other hand, other growing demand regions, such as Japan and South-Korea were also not considered [72]. For a complete analysis on potential wood pellet imports, the local competition for feedstock as well as the international competition for pellets needs to be considered in future work.

\subsection{Supply Chain Optimizations}

Certain supply chain optimization options, such as the use of rail transport instead of road transport and the use of larger ships were not included in this study. Further research on the impact of several optimization strategies could provide additional results. Stricter future GHG criteria, as analysed in this work, could push towards the realization of such supply chain optimizations. Stricter criteria, and ongoing developments in renewable energy technologies will furthermore lower emissions of future electricity production, thereby lowering emissions of particularly pelletization. This is especially relevant for countries such as Latvia and Estonia, that have a higher than average emission factor and an obligation to meet EU regulated emission targets.

An optimization aspect which was analysed is the production of torrefied pellets. This study has shown that importing TOP can result in a larger import potential that meets GHG reduction criteria. A drawback of TOP imports is that the transition from the use of biomass for energy production to material production becomes limited to thermochemical routes, since biochemical conversion is not feasible using TOP.

A promising use of biomass to achieve negative emissions is the utilization of wood pellets in bio-energy plants combined with carbon capture and storage (BECCS). The largest global consumer of wood pellets, the Drax Power Station in the UK is aiming to transition towards the use of BECCS. Emission savings through carbon capture and storage can be subtracted from supply chain emissions according to the RED II prescribed methodology, thereby potentially resulting in a much larger import potential [1]. Still, this does not take away the necessity of focussing on optimization of supply chains. Especially with the deployment of a costly, advanced technology such as BECCS it is important to maximize the GHG saving potential, even more so since carbon capture and storage requires energy, thereby increasing biomass consumption [73].

\subsection{Necessity of Including Spatially Explicit Cost and Emission Calculations}

Results show that pellet production and import potentials against acceptable costs and emissions depends on the availability of feedstock close to export ports. This also points at the shortcomings of 
integrated assessment models in not considering the spatially explicit cost variation of potential pellet supply. If models, for instance, do not include inland transport cost variation, this could result in an underestimation of costs and emissions of more than a factor of 2, likely resulting in very different results and conclusions on the potential of biomass trade. Supply chain costs and emissions in this study were calculated to the ARA region. Global assessment models should ideally use spatially explicit calculations for all export ports considered in the global trade of pellets, as well as consider potential infrastructure developments.

In the future, other markets besides electricity and heat production are likely to become more important, such as the use of biomass for the production of advanced transport fuels or biomaterials. Also for these end-uses import of (solid) biomass feedstocks may in principle be a viable option [74], especially since GHG reduction criteria for these end-uses are less strict, requiring at least $65 \%$ savings for produced bioliquids and biofuels consumed in the transport sector [1]. Further work needs to be done to analyse different production routes and supply chains. For commodities such as transport fuels, it is especially interesting to consider the locations of pre-treatment, production and consumption. From a global emission perspective, it could be best to produce these fuels closer to the source of biomass rather than trading wood pellets to be upgraded in import regions. The most emission savings could be realized by not trading biofuels and instead focussing on maximized local utilization of biomass resources. On the other hand, the lack of biomass availability in many countries will likely only increase the demand for biomass imports. Some countries with large feedstock availability, like Brazil, have several other options of producing renewable energy, such as hydropower. Investments in biomass mobilization infrastructure and pellet production facilities could on the longer-term benefit sourcing countries in supplying local bioenergy as well as trading surplus biomass to countries with fewer resources.

\section{Conclusions}

This study has shown large differences in supply chain costs and emissions of pellets imported from different countries to the CIF ARA region. Cost for procuring feedstock is the largest part of most supply chains and determines to a large extent the order of countries. The difference between the lowest and highest costs is a factor 3, ranging between 90 and $280 € / \mathrm{t}$ pellets for the total production potential calculated. The impact of inland transport is large, adding up to almost $150 € / \mathrm{t}$ pellets to the total supply chain costs. Pellets exported from the United States for instance range from 103 to $252 € / \mathrm{t}$ pellets CIF ARA, when varying the transport distance from pellet mills between 0 and $2000 \mathrm{~km}$ for pellet mills that are located far inland. The costs and emissions calculated in this study are based on several assumptions and are therefore uncertain to some degree. What is however considered very robust, is the large relative impact of feedstock availability and transport distance on total costs and emissions. This work therefore shows the importance of considering spatial feedstock availability and competition in assessments on the potential contribution of bioenergy.

The cost limits analysed in this study clearly show diminished potentials for a cost limit of $150 € / t$ and especially $125 € / t$. In the case of $125 € / t$, production would be limited to only the coastal areas of Brazil and SE US. These costs are considered a good representation of spot and contract prices in previous years, even though no direct comparison can be made since pellet prices include profit margins for the different supply chain actors. Spot prices have varied between 110 and $160 € / \mathrm{t}$ pellets between 2012 and 2017 and contract prices in the US and Canada have varied between 95 and $180 € / t$ pellets in the same years [21]. Increasing demand for pellets could result in higher prices and more opportunities for supply chain optimizations, thereby increasing maximum supply chain costs. On the other hand, wood pellet consumption in previous years has been subsidized. If these subsidies were to be removed, the paying capacity and therefore maximum supply chain costs would reduce.

Stricter GHG thresholds have a significant impact on import potentials, especially in the case of electricity production. If the minimum GHG saving threshold is increased from $70 \%$ to $80 \%$, the total potential will reduce from 61 to $16 \mathrm{Mt}$ in the case of electricity production from pellets. With an $85 \%$ 
reduction threshold, only $1 \mathrm{Mt}$ of the total export potential remains. For heat production, potentials decrease from $61 \mathrm{Mt}$ under a $70 \%$ threshold, to 13 and $0.5 \mathrm{Mt}$ using the stricter criteria. A shift to TOP would increase potentials to $39 \mathrm{Mt}$ and $36 \mathrm{Mt}$ for electricity and heat production respectively under the $80 \%$ criterium. The additional potential for TOP is however limited in the case of the $85 \%$ threshold, resulting in a total of $4 \mathrm{Mt}$. The sharp reductions of potentials towards the $85 \%$ threshold clearly indicates an upper limit for international trade of wood pellets and TOP. Increasing GHG thresholds will result in larger relative emission savings, but could also limit the amount of biomass use, and as such postpone the further decarbonisation of the European economy. Policy makers need to be aware of this trade-off between ambitious GHG thresholds and the potential contribution of biomass to renewable energy targets.

Author Contributions: Conceptualization, L.V., R.H and M.J.; methodology, L.V., R.H and M.J.; formal analysis, L.V.; investigation, L.V.; writing—original draft preparation, L.V.; writing—review and editing, L.V, R.H. and M.J.; visualization, L.V.; supervision, R.H. and M.J.; project administration, M.J.; funding acquisition, M.J. All authors have read and agreed to the published version of the manuscript.

Funding: This research was funded by the Subsidieregeling Energie en Innovatie Biobased Economy: Kostprijsreductie Elektriciteit-en Warmteproductie, grant number No.TEBE213008.

Conflicts of Interest: The authors declare no conflict of interest.

\section{Appendix A}

Table A1. Feedstock costs for the different feedstock types, in $€ / t$ of wet feedstock.

\begin{tabular}{ccccc}
\hline Country & Pulpwood & Logging Residues & Sawmill Residues & Source \\
\hline US SE & 30 & 30 & 30 & {$[32]$} \\
US NE & 35.2 & 35.2 & 35.2 & {$[33]$} \\
Canada SE & 35.2 & 35.2 & 35.2 & {$[33]$} \\
Canada BC & 36.2 & 36.2 & 36.2 & {$[33]$} \\
Brazil & 22.4 & 22.4 & 22.4 & {$[33]$} \\
Estonia & 28.6 & 25.7 & 25.7 & {$[34]$} \\
Lithuania & 57.9 & 52.1 & 52.1 & {$[35]$} \\
Latvia & 56.8 & 42.5 & 42.5 & {$[75]$} \\
Russia & 39.3 & 35.4 & 35.4 & {$[36]$} \\
\hline
\end{tabular}

Table A2. Diesel costs used in this study, in $€ / L$.

\begin{tabular}{ccc}
\hline Country & Diesel Price & Source \\
\hline Netherlands & 1.39 & {$[76]$} \\
US SE & 0.70 & {$[77,78]$} \\
US NE & 0.70 & {$[77,78]$} \\
Canada SE & 0.85 & {$[79,80]$} \\
Canada BC & 0.85 & {$[79,80]$} \\
Brazil & 0.81 & {$[81,82]$} \\
Estonia & 1.39 & {$[76]$} \\
Lithuania & 1.18 & {$[76]$} \\
Latvia & 1.25 & {$[76]$} \\
Russia & 0.62 & {$[83,84]$} \\
\hline
\end{tabular}

Table A3. Hourly labor costs in the manufacturing industry used in this study, in $€ / \mathrm{h}$.

\begin{tabular}{ccc}
\hline Country & Costs $(\mathbf{E} /$ hour $)$ & Source \\
\hline Netherlands & 35.9 & {$[85]$} \\
US SE & 34.6 & {$[86]$} \\
US NE & 34.6 & {$[86]$} \\
Canada SE & 26.7 & {$[86]$} \\
Canada BC & 26.7 & {$[86]$} \\
Brazil & 7.1 & {$[86]$} \\
Estonia & 12.4 & {$[85]$} \\
Lithuania & 9.0 & {$[85]$} \\
Latvia & 9.3 & {$[85]$} \\
Russia & 3.1 & {$[87]$} \\
\hline
\end{tabular}


Table A4. Grid electricity costs used in this study, in $€ / \mathrm{kWh}$.

\begin{tabular}{ccccc}
\hline Country & Costs & Type & Period & Source \\
\hline Netherlands & 0.0680 & $>150,000 \mathrm{MWh}$, incl. taxes & 2018 & {$[88]$} \\
US SE & 0.0582 & Industrial sector, retail price & 2018 & {$[89]$} \\
US NE & 0.0582 & Industrial sector, retail price & 2018 & {$[89]$} \\
Canada SE & 0.0564 & Industrial sector, incl. taxes & 2017 & {$[90]$} \\
Canada BC & 0.0705 & Industrial sector, incl. taxes & 2017 & {$[90]$} \\
Brazil & 0.1427 & General data & 2018 & {$[82,91]$} \\
Estonia & 0.1109 & $500-2500 \mathrm{MWh}$, non-household, incl. taxes & $2018 \mathrm{~S} 2$ & {$[92]$} \\
Lithuania & 0.1089 & $500-2500 \mathrm{MWh}$, non-household, incl. taxes & $2018 \mathrm{~S} 2$ & {$[92]$} \\
Latvia & 0.1267 & $500-2500 \mathrm{MWh}$, non-household, incl. taxes & $2018 \mathrm{~S} 2$ & {$[92]$} \\
Russia & 0.0139 & General data & 2017 & {$[93]$} \\
\hline
\end{tabular}

Table A5. Shipping fuel and charter costs variation, in $€ / t$ for fuel costs and $€ /$ day for charter costs.

\begin{tabular}{cccccc}
\hline Scenario & $\begin{array}{c}\text { Fuel Costs } \\
\text { (IFO380) }\end{array}$ & Source & $\begin{array}{c}\text { Charter Costs } \\
\text { Handymax }\end{array}$ & Period & Source \\
\hline Low & 300 & {$[94]$} & 2000 & 2018 & {$[95]$} \\
Medium & 400 & {$[94]$} & 6000 & 2018 & {$[95]$} \\
High & 500 & {$[94]$} & 10,000 & 2018 & {$[95]$} \\
\hline
\end{tabular}

${ }^{1}$ Handysize costs are assumed to be $10 \%$ lower and Supramax costs are assumed to be $10 \%$ higher.

\section{Appendix B}

Table A6. Pelletizing costs and GHG factors, for a small (50 kt/y) and large (500 kt/y) pellet mill in the United States, based on data from Visser et al. [37].

\begin{tabular}{|c|c|c|c|c|c|c|}
\hline Parameter & Unit & $\begin{array}{l}\text { Small } \\
\text { Pellets }\end{array}$ & $\begin{array}{l}\text { Large } \\
\text { Pellets }\end{array}$ & $\begin{array}{c}\text { Small } \\
\text { TOP }\end{array}$ & $\begin{array}{l}\text { Large } \\
\text { TOP }\end{array}$ & Source \\
\hline CAPEX & $€ / t$ pellets & 14.1 & 7.9 & 17.3 & 10.2 & [37] \\
\hline CAPEX, sawmill residues ${ }^{1}$ & $€ / t$ pellets & 11.5 & 6.1 & 16.0 & 9.3 & [37] \\
\hline CAPEX torrefaction reactor ${ }^{2}$ & $€ / t$ pellets & & & 4.5 & 3.2 & [96] \\
\hline Service \& Maintenance & $€ / t$ pellets & 5.0 & 5.0 & 5.0 & 5.0 & \\
\hline Labor $^{3}$ & $€ / t$ pellets & 13.1 & 7.4 & 13.1 & 7.4 & \\
\hline \multicolumn{7}{|l|}{ Energy requirements } \\
\hline Drying & $\begin{array}{l}\mathrm{kWh} / \mathrm{t} \\
\text { pellets }\end{array}$ & 36 & 36 & 36 & 36 & [37] \\
\hline Course grinding 4 & $\begin{array}{l}\mathrm{kWh} / \mathrm{t} \\
\text { pellets }\end{array}$ & 20 & 20 & 20 & 20 & [37] \\
\hline Grinding ${ }^{5}$ & $\begin{array}{l}\mathrm{kWh} / \mathrm{t} \\
\text { pellets }\end{array}$ & 31 & 31 & 15.5 & 15.5 & [37] \\
\hline Pelletizing & $\begin{array}{l}\mathrm{kWh} / \mathrm{t} \\
\text { pellets }\end{array}$ & 78 & 78 & 78 & 78 & [37] \\
\hline Cooling & $\begin{array}{l}\mathrm{kWh} / \mathrm{t} \\
\text { pellets }\end{array}$ & 4 & 4 & 4 & 4 & [37] \\
\hline Peripheral equipment & $\begin{array}{l}\mathrm{kWh} / \mathrm{t} \\
\text { pellets }\end{array}$ & 16 & 16 & 16 & 16 & [37] \\
\hline Torrefaction & $\begin{array}{l}\mathrm{kWh} / \mathrm{t} \\
\text { pellets }\end{array}$ & & & 21 & 21 & [28] \\
\hline Required heat & $\mathrm{kWh} / \mathrm{t}$ ev. w. & 1200 & 1200 & 1200 & 1200 & [39] \\
\hline Boiler efficiency & & $85 \%$ & $85 \%$ & $85 \%$ & $85 \%$ & \\
\hline
\end{tabular}

${ }^{1}$ Based on Visser et al. [37], assumed scale factor of 0.85 , and a reference pellet plant size of $100 \mathrm{kt} / \mathrm{a}$. The difference between costs of sawmill residues and other feedstocks is the cost of grinding equipment; ${ }^{2}$ Based on investment costs of $5.5 \mathrm{M} €$ for an annual production of $200 \mathrm{kt} / \mathrm{a}$ [96]. Assumed interest rate of $10 \%$ and lifetime of 15 years. Assumed scale factor of $0.85 ;{ }^{3}$ Based on Visser et al. [37], assumed economies of scale factor of 0.25 , and a reference pellet plant size of $100 \mathrm{kt} / \mathrm{a}$. Based on costs in the United States, labour costs in other countries are calculated based on the percentage of hourly wages in the United States; ${ }^{4}$ Only required for pulpwood.; ${ }^{5}$ As reported by Wang et al. [97], the energy requirement of grinding is reduced by half for torrefied material. 
Appendix C

Table A7. Methodology used for the calculation of available feedstock.

\begin{tabular}{|c|c|c|c|c|}
\hline Country & \multicolumn{2}{|c|}{ Forest Area } & Annual Increment & Restricted Area \\
\hline $\begin{array}{l}\text { Estonia } \\
\text { Latvia } \\
\text { Lithuania }\end{array}$ & \multicolumn{2}{|c|}{$\begin{array}{l}\text { Predicted volume of wood production per } \mathrm{km}^{2} \text {, based on statistics, } \\
\text { productivity and tree species composition }[60,98]\end{array}$} & \multicolumn{2}{|c|}{ Assumed to be included in Forest area estimate } \\
\hline Russia & \multicolumn{2}{|c|}{ Forest cover dataset of all forested areas in Russia [99]. } & $\begin{array}{l}\text { Growing stock estimates per } \\
\text { administrative division, average } \\
\text { annual increment per growing stock } \\
\text { factor for the entire country [100] }{ }^{1} \text {. }\end{array}$ & - \\
\hline Canada & \multicolumn{2}{|c|}{$\begin{array}{c}\text { Canada's Forest Inventory 2001-data on percentage forested area and } \\
\text { predominant species [101]. Productivity was calculated based on the } \\
\text { percentage of forested area and the annual increment. }\end{array}$} & $\begin{array}{l}\text { Productivity varied for different } \\
\text { ecoregions, based on five ecozones. } \\
\text { Other regions were based on } \\
\text { temperature differences and } \\
\text { geographic proximity, mainly the } \\
\text { latitude [102] }{ }^{2} \text {. }\end{array}$ & $\begin{array}{l}\text { The extent of intact forests in } 2010 \\
\text { was subtracted, based on spatial data } \\
\text { from [103]. }\end{array}$ \\
\hline US & \multicolumn{3}{|c|}{$\begin{array}{l}\text { Average annual volume growth based on USDA Forest Inventory and Analysis (FIA) data [104]. Data consists of } \\
\text { most recent data per county from 2015, } 2016 \text { and } 2017^{3} \text {. }\end{array}$} & $\begin{array}{l}\text { Old forest areas, from a database of } \\
\text { relative forest intactness were } \\
\text { subtracted, based on [105], taken } \\
\text { from [106]. }\end{array}$ \\
\hline Brazil & $\begin{array}{c}\text { Based on land coverage and use } \\
\text { database of the Instituto Brasiliero de } \\
\text { Geografia e Estatistica [65]. Areas } \\
\text { classified as forest vegetation were } \\
\text { included. }\end{array}$ & \multicolumn{2}{|c|}{$\begin{array}{l}\text { Mean annual increment data for pine, eucalyptus and Brazilian firetree } \\
{[107,108] \text {. In states with tropical wood vegetation, the firetree value was }} \\
\text { used. In other states, an average of pine and eucalyptus was used, except } \\
\text { for states where one species is dominant, based on [109] }{ }^{4} \text {. }\end{array}$} & $\begin{array}{l}\text { Areas classified as (1) indigenous } \\
\text { land, (2) protected or established for } \\
\text { sustainable use only and (3) intact } \\
\text { forest areas were subtracted [66-68]. }\end{array}$ \\
\hline \multicolumn{5}{|c|}{$\begin{array}{l}{ }^{1} \text { This is considered a suboptimal approach, made necessary by a lack of data. In reality the link between growing stock and annual increment is non-linearly and depends on aspects such } \\
\text { as tree species, age and climate; }{ }^{2} \text { Growth in the Taiga Shield and Taiga Plains ecozones were calculated based on the assessment of the impact of temperature increase on productivity in } \\
\text { Eastern Canada, assuming an equal productivity difference between the warmer Boreal zones and the Taiga zones [110]. Average temperature differences range between } 7.5^{\circ} \mathrm{C} \text { in January } \\
\text { and } 4{ }^{\circ} \mathrm{C} \text { in July [111], based on this the results for the highest temperature difference of } 4{ }^{\circ} \mathrm{C} \text { were used, calculated for the dominant tree species in the ecozones [110]. Atlantic Maritime, } \\
\text { Boreal Plains, Boreal Shield, Montane Cordillera, Pacific Maritime. Other ecozones were based on the existing data: Boreal Cordillera/Taiga Cordillera = Taiga Plain, Artic Cordillera, } \\
\text { Southern Arctic = Taiga Shield, Mixedwood Plains = Atlantic Maritime, Hudson Plains = Average Taiga Shield \& Boreal Shield, Prairies = Average Montane Cordillera \& Boreal Shield; } \\
{ }^{3} \text { FIA data is based on measured plots within a grid overlay across the conterminous US. The location of plots however varies, and some plots are swapped within a country for privacy } \\
\text { reasons. For this reason, the results aggregated per county were used, instead of actual plot data. Country aggregates are subsequently averaged across the area, assuming a homogenous } \\
\text { spread to obtain a } 1 \mathrm{~km}{ }^{2} \text { raster dataset; }{ }^{4} \text { Eucalyptus: Sao Paolo, Minas Gerais, Espirito Santo. Pine: Sao Paolo, Mato Grosso, Parana, Santa Catarina, Rio Grande do Sul. Eucalyptus + Pine: } \\
\text { Goias, Federal district, Bahia, Piaui, Ceara, Rio Grande do Norte, Paraiba, Pernambuco, Alagoas, Sergipe. Tropical wood: Acre, Amazonas, Roraima, Rondônia, Mato Grosso, Pará, Amapá, } \\
\text { Tocantins, Maranhão. }\end{array}$} \\
\hline
\end{tabular}




\section{Appendix D}

Table A8. Overview of supply chain costs of pellets produced from sawmill residues, transported over $500 \mathrm{~km}$ to export ports and including $50 \mathrm{~km}$ feedstock transport, in $€ / \mathrm{t}$ pellets. Components included in the table: 1. Feedstock transport; 2. Feedstock; 3. Pelletizing; 4. Pellet transport; 5. Shipping; 6. Port operations.

\begin{tabular}{cccccccc}
\hline Export Port & Total & $\mathbf{1}$ & $\mathbf{2}$ & $\mathbf{3}$ & $\mathbf{4}$ & $\mathbf{5}$ & $\mathbf{6}$ \\
\hline Savannah & 140.9 & 8.4 & 55.6 & 22.3 & 37.2 & 15.1 & 2.2 \\
Mobile & 144.5 & 8.4 & 55.6 & 22.3 & 37.2 & 18.7 & 2.2 \\
Norfolk & 139.2 & 8.4 & 55.6 & 22.3 & 37.2 & 13.4 & 2.2 \\
Portland & 147.6 & 8.4 & 65.2 & 22.9 & 37.2 & 11.7 & 2.2 \\
Halifax & 141.7 & 7.8 & 65.2 & 21.2 & 34.9 & 10.4 & 2.2 \\
Montreal & 142.2 & 7.8 & 65.2 & 21.2 & 34.9 & 10.9 & 2.2 \\
Quebec & 141.8 & 7.8 & 65.2 & 21.2 & 34.9 & 10.4 & 2.2 \\
Vancouver & 170.3 & 7.8 & 67.1 & 21.3 & 34.9 & 36.9 & 2.3 \\
Prince Rupert & 171.2 & 7.8 & 67.1 & 21.3 & 34.9 & 37.8 & 2.3 \\
Maceio & 107.3 & 5.4 & 41.6 & 15.4 & 24.8 & 17.5 & 2.6 \\
Salvador & 108.2 & 5.4 & 41.6 & 15.4 & 24.8 & 18.4 & 2.6 \\
Rio de Janeiro & 110.6 & 5.4 & 41.6 & 15.4 & 24.8 & 20.8 & 2.6 \\
Rio Grande & 113.4 & 5.4 & 41.6 & 15.4 & 24.8 & 23.6 & 2.6 \\
St. Petersburg & 134.5 & 4.3 & 75.5 & 16.4 & 19.7 & 16.5 & 2.0 \\
Paldiski & 132.0 & 7.6 & 54.9 & 17.5 & 35.6 & 14.1 & 2.2 \\
Kunda & 133.1 & 7.6 & 54.9 & 17.5 & 35.6 & 15.3 & 2.2 \\
Pärnu & 131.5 & 7.6 & 54.9 & 17.5 & 35.6 & 13.7 & 2.2 \\
Ventspils & 163.3 & 6.9 & 90.7 & 18.8 & 32.0 & 12.6 & 2.3 \\
Liepaja & 162.8 & 6.9 & 90.7 & 18.8 & 32.0 & 12.1 & 2.3 \\
Riga & 164.4 & 6.9 & 90.7 & 18.8 & 32.0 & 13.7 & 2.3 \\
Butinge & 182.2 & 6.6 & 111.1 & 19.9 & 30.8 & 11.5 & 2.2 \\
Klaipeda & 182.2 & 6.6 & 111.1 & 19.9 & 30.8 & 11.5 & 2.2 \\
\hline
\end{tabular}

Table A9. Overview of supply chain costs of pellets produced from roundwood, transported over $500 \mathrm{~km}$ to export ports and including $50 \mathrm{~km}$ feedstock transport, in $€ / \mathrm{t}$ pellets. Components included in the table: 1. Feedstock transport; 2. Feedstock; 3. Pelletizing; 4. Pellet transport; 5. Shipping; 6. Port operations.

\begin{tabular}{cccccccc}
\hline Export Port & Total & $\mathbf{1}$ & $\mathbf{2}$ & $\mathbf{3}$ & $\mathbf{4}$ & $\mathbf{5}$ & $\mathbf{6}$ \\
\hline Savannah & 156.0 & 10.0 & 55.6 & 35.9 & 37.2 & 15.1 & 2.2 \\
Mobile & 159.6 & 10.0 & 55.6 & 35.9 & 37.2 & 18.7 & 2.2 \\
Norfolk & 154.3 & 10.0 & 55.6 & 35.9 & 37.2 & 13.4 & 2.2 \\
Portland & 164.5 & 10.0 & 65.2 & 38.2 & 37.2 & 11.7 & 2.2 \\
Halifax & 158.4 & 9.3 & 65.2 & 36.3 & 34.9 & 10.4 & 2.2 \\
Montreal & 158.9 & 9.3 & 65.2 & 36.3 & 34.9 & 10.9 & 2.2 \\
Quebec & 158.5 & 9.3 & 65.2 & 36.3 & 34.9 & 10.4 & 2.2 \\
Vancouver & 187.4 & 9.3 & 67.1 & 36.8 & 34.9 & 36.9 & 2.3 \\
Prince Rupert & 188.3 & 9.3 & 67.1 & 36.8 & 34.9 & 37.8 & 2.3 \\
Maceio & 118.9 & 6.6 & 41.6 & 25.9 & 24.8 & 17.5 & 2.6 \\
Salvador & 119.8 & 6.6 & 41.6 & 25.9 & 24.8 & 18.4 & 2.6 \\
Rio de Janeiro & 122.1 & 6.6 & 41.6 & 25.9 & 24.8 & 20.8 & 2.6 \\
Rio Grande & 125.0 & 6.6 & 41.6 & 25.9 & 24.8 & 23.6 & 2.6 \\
St. Petersburg & 162.1 & 5.2 & 83.9 & 34.8 & 19.7 & 16.5 & 2.0 \\
Paldiski & 154.5 & 9.3 & 61.0 & 32.3 & 35.6 & 14.1 & 2.2 \\
Kunda & 155.7 & 9.3 & 61.0 & 32.3 & 35.6 & 15.3 & 2.2 \\
Pärnu & 154.1 & 9.3 & 61.0 & 32.3 & 35.6 & 13.7 & 2.2 \\
Ventspils & 184.5 & 8.4 & 90.7 & 38.5 & 32.0 & 12.6 & 2.3 \\
Liepaja & 184.0 & 8.4 & 90.7 & 38.5 & 32.0 & 12.1 & 2.3 \\
Riga & 185.5 & 8.4 & 90.7 & 38.5 & 32.0 & 13.7 & 2.3 \\
Butinge & 222.2 & 8.1 & 123.5 & 46.1 & 30.8 & 11.5 & 2.2 \\
Klaipeda & 222.2 & 8.1 & 123.5 & 46.1 & 30.8 & 11.5 & 2.2 \\
\hline
\end{tabular}


Table A10. Overview of supply chain costs of torrefied pellets produced from sawmill residues, transported over $500 \mathrm{~km}$ to export ports and including $50 \mathrm{~km}$ feedstock transport, in $€ / \mathrm{t}$ pellets. Components included in the table: 1. Feedstock transport; 2. Feedstock; 3. Pelletizing; 4. Pellet transport; 5. Shipping; 6. Port operations.

\begin{tabular}{cccccccc}
\hline Export Port & Total & $\mathbf{1}$ & $\mathbf{2}$ & $\mathbf{3}$ & $\mathbf{4}$ & $\mathbf{5}$ & $\mathbf{6}$ \\
\hline Savannah & 155.3 & 7.5 & 63.6 & 32.1 & 35.7 & 14.2 & 2.2 \\
Mobile & 158.8 & 7.5 & 63.6 & 32.1 & 35.7 & 17.6 & 2.2 \\
Norfolk & 153.8 & 7.5 & 63.6 & 32.1 & 35.7 & 12.6 & 2.2 \\
Portland & 163.1 & 7.5 & 74.5 & 32.1 & 35.7 & 11.0 & 2.2 \\
Halifax & 163.8 & 8.0 & 74.5 & 31.4 & 37.8 & 9.8 & 2.2 \\
Montreal & 164.2 & 8.0 & 74.5 & 31.4 & 37.8 & 10.2 & 2.2 \\
Quebec & 163.8 & 8.0 & 74.5 & 31.4 & 37.8 & 9.8 & 2.2 \\
Vancouver & 193.5 & 8.0 & 76.7 & 33.8 & 37.8 & 34.9 & 2.3 \\
Prince Rupert & 194.3 & 8.0 & 76.7 & 33.8 & 37.8 & 35.7 & 2.3 \\
Maceio & 140.7 & 5.6 & 47.5 & 42.3 & 26.2 & 16.5 & 2.6 \\
Salvador & 141.5 & 5.6 & 47.5 & 42.3 & 26.2 & 17.4 & 2.6 \\
Rio de Janeiro & 143.8 & 5.6 & 47.5 & 42.3 & 26.2 & 19.6 & 2.6 \\
Rio Grande & 146.4 & 5.6 & 47.5 & 42.3 & 26.2 & 22.3 & 2.6 \\
St. Petersburg & 144.8 & 4.2 & 86.3 & 17.4 & 19.7 & 15.2 & 2.0 \\
Paldiski & 157.3 & 7.7 & 62.8 & 36.1 & 35.6 & 13.0 & 2.2 \\
Kunda & 158.3 & 7.7 & 62.8 & 36.1 & 35.6 & 14.0 & 2.2 \\
Pärnu & 156.9 & 7.7 & 62.8 & 36.1 & 35.6 & 12.6 & 2.2 \\
Ventspils & 194.5 & 6.9 & 103.7 & 38.0 & 32.0 & 11.6 & 2.3 \\
Liepaja & 194.0 & 6.9 & 103.7 & 38.0 & 32.0 & 11.2 & 2.3 \\
Riga & 195.5 & 6.9 & 103.7 & 38.0 & 32.0 & 12.6 & 2.3 \\
Butinge & 212.2 & 6.7 & 127.0 & 34.9 & 30.8 & 10.6 & 2.2 \\
Klaipeda & 212.2 & 6.7 & 127.0 & 34.9 & 30.8 & 10.6 & 2.2 \\
\hline
\end{tabular}

Table A11. Overview of supply chain costs of torrefied pellets produced from roundwood, transported over $500 \mathrm{~km}$ to export ports and including $50 \mathrm{~km}$ feedstock transport, in $€ / \mathrm{t}$ pellets. Components included in the table: 1. Feedstock transport; 2. Feedstock; 3. Pelletizing; 4. Pellet transport; 5. Shipping; 6. Port operations.

\begin{tabular}{cccccccc}
\hline Export Port & Total & $\mathbf{1}$ & $\mathbf{2}$ & $\mathbf{3}$ & $\mathbf{4}$ & $\mathbf{5}$ & $\mathbf{6}$ \\
\hline Savannah & 159.3 & 9.3 & 63.6 & 34.3 & 35.7 & 14.2 & 2.2 \\
Mobile & 162.8 & 9.3 & 63.6 & 34.3 & 35.7 & 17.6 & 2.2 \\
Norfolk & 157.7 & 9.3 & 63.6 & 34.3 & 35.7 & 12.6 & 2.2 \\
Portland & 167.1 & 9.3 & 74.5 & 34.3 & 35.7 & 11.0 & 2.2 \\
Halifax & 167.9 & 9.9 & 74.5 & 33.5 & 37.8 & 9.8 & 2.2 \\
Montreal & 168.3 & 9.9 & 74.5 & 33.5 & 37.8 & 10.2 & 2.2 \\
Quebec & 167.9 & 9.9 & 74.5 & 33.5 & 37.8 & 9.8 & 2.2 \\
Vancouver & 197.8 & 9.9 & 76.7 & 36.2 & 37.8 & 34.9 & 2.3 \\
Prince Rupert & 198.7 & 9.9 & 76.7 & 36.2 & 37.8 & 35.7 & 2.3 \\
Maceio & 146.1 & 7.1 & 47.5 & 46.2 & 26.2 & 16.5 & 2.6 \\
Salvador & 147.0 & 7.1 & 47.5 & 46.2 & 26.2 & 17.4 & 2.6 \\
Rio de Janeiro & 149.2 & 7.1 & 47.5 & 46.2 & 26.2 & 19.6 & 2.6 \\
Rio Grande & 151.8 & 7.1 & 47.5 & 46.2 & 26.2 & 22.3 & 2.6 \\
St. Petersburg & 156.7 & 5.3 & 95.9 & 18.6 & 19.7 & 15.2 & 2.0 \\
Paldiski & 169.5 & 9.9 & 69.7 & 39.2 & 35.6 & 13.0 & 2.2 \\
Kunda & 170.6 & 9.9 & 69.7 & 39.2 & 35.6 & 14.0 & 2.2 \\
Pärnu & 169.2 & 9.9 & 69.7 & 39.2 & 35.6 & 12.6 & 2.2 \\
Ventspils & 199.9 & 8.9 & 103.7 & 41.5 & 32.0 & 11.6 & 2.3 \\
Liepaja & 199.4 & 8.9 & 103.7 & 41.5 & 32.0 & 11.2 & 2.3 \\
Riga & 200.9 & 8.9 & 103.7 & 41.5 & 32.0 & 12.6 & 2.3 \\
Butinge & 231.2 & 8.5 & 141.1 & 38.0 & 30.8 & 10.6 & 2.2 \\
Klaipeda & 231.3 & 8.5 & 141.1 & 38.0 & 30.8 & 10.6 & 2.2 \\
\hline
\end{tabular}




\section{Appendix E}

Table A12. Overview of supply chain GHG emissions of pellets produced from sawmill residues, transported over $500 \mathrm{~km}$ to export ports and including $50 \mathrm{~km}$ feedstock transport, in $\mathrm{kg} \mathrm{CO}_{2}$-eq/t pellets. Components included in the table: 1 . Silviculture and harvest; 2. Feedstock transport; 3. Pelletizing; 4. Pellet transport; 5. Shipping; 6. Port operations.

\begin{tabular}{cccccccc}
\hline Export Port & Total & $\mathbf{1}$ & $\mathbf{2}$ & $\mathbf{3}$ & $\mathbf{4}$ & $\mathbf{5}$ & $\mathbf{6}$ \\
\hline Savannah & 12.5 & 1.1 & 4.5 & 2.7 & 0.2 & 2.9 & 1.1 \\
Mobile & 13.2 & 1.1 & 4.5 & 2.7 & 0.2 & 3.6 & 1.1 \\
Norfolk & 12.2 & 1.1 & 4.5 & 2.7 & 0.2 & 2.6 & 1.1 \\
Portland & 11.8 & 1.1 & 4.5 & 2.7 & 0.2 & 2.2 & 1.1 \\
Halifax & 8.8 & 1.1 & 1.7 & 2.7 & 0.2 & 2.0 & 1.1 \\
Montreal & 8.9 & 1.1 & 1.7 & 2.7 & 0.2 & 2.1 & 1.1 \\
Quebec & 8.8 & 1.1 & 1.7 & 2.7 & 0.2 & 2.0 & 1.1 \\
Vancouver & 13.9 & 1.1 & 1.7 & 2.7 & 0.2 & 7.1 & 1.1 \\
Prince Rupert & 14.0 & 1.1 & 1.7 & 2.7 & 0.2 & 7.2 & 1.1 \\
Maceio & 9.3 & 1.1 & 0.9 & 2.7 & 0.1 & 3.4 & 1.1 \\
Salvador & 9.4 & 1.1 & 0.9 & 2.7 & 0.1 & 3.5 & 1.1 \\
Rio de Janeiro & 9.9 & 1.1 & 0.9 & 2.7 & 0.1 & 4.0 & 1.1 \\
Rio Grande & 10.4 & 1.1 & 0.9 & 2.7 & 0.1 & 4.5 & 1.1 \\
St. Petersburg & 12.2 & 1.1 & 4.9 & 2.7 & 0.2 & 2.2 & 1.1 \\
Paldiski & 15.0 & 1.1 & 7.9 & 2.7 & 0.3 & 1.9 & 1.1 \\
Kunda & 15.1 & 1.1 & 7.9 & 2.7 & 0.3 & 2.0 & 1.1 \\
Pärnu & 14.9 & 1.1 & 7.9 & 2.7 & 0.3 & 1.8 & 1.1 \\
Ventspils & 17.0 & 1.1 & 10.1 & 2.7 & 0.3 & 1.7 & 1.1 \\
Liepaja & 16.9 & 1.1 & 10.1 & 2.7 & 0.3 & 1.6 & 1.1 \\
Riga & 17.1 & 1.1 & 10.1 & 2.7 & 0.3 & 1.8 & 1.1 \\
Butinge & 10.0 & 1.1 & 3.4 & 2.7 & 0.2 & 1.5 & 1.1 \\
Klaipeda & 10.0 & 1.1 & 3.4 & 2.7 & 0.2 & 1.5 & 1.1 \\
\hline
\end{tabular}

Table A13. Overview of supply chain GHG emissions of pellets produced from roundwood, transported over $500 \mathrm{~km}$ to export ports and including $50 \mathrm{~km}$ feedstock transport, in $\mathrm{kg} \mathrm{CO}_{2}$-eq/t pellets. Components included in the table: 1 . Silviculture and harvest; 2. Feedstock transport; 3. Pelletizing; 4. Pellet transport; 5. Shipping; 6. Port operations.

\begin{tabular}{cccccccc}
\hline Export Port & Total & $\mathbf{1}$ & $\mathbf{2}$ & $\mathbf{3}$ & $\mathbf{4}$ & $\mathbf{5}$ & $\mathbf{6}$ \\
\hline Savannah & 16.9 & 2.5 & 2.2 & 6.1 & 2.7 & 0.2 & 2.9 \\
Mobile & 17.6 & 2.5 & 2.2 & 6.1 & 2.7 & 0.2 & 3.6 \\
Norfolk & 16.6 & 2.5 & 2.2 & 6.1 & 2.7 & 0.2 & 2.6 \\
Portland & 16.3 & 2.5 & 2.2 & 6.1 & 2.7 & 0.2 & 2.2 \\
Halifax & 12.9 & 2.5 & 2.2 & 3.0 & 2.7 & 0.2 & 2.0 \\
Montreal & 12.9 & 2.5 & 2.2 & 3.0 & 2.7 & 0.2 & 2.1 \\
Quebec & 12.9 & 2.5 & 2.2 & 3.0 & 2.7 & 0.2 & 2.0 \\
Vancouver & 17.9 & 2.5 & 2.2 & 3.0 & 2.7 & 0.2 & 7.1 \\
Prince Rupert & 18.1 & 2.5 & 2.2 & 3.0 & 2.7 & 0.2 & 7.2 \\
Maceio & 13.3 & 2.5 & 2.2 & 2.1 & 2.7 & 0.1 & 3.4 \\
Salvador & 13.5 & 2.5 & 2.2 & 2.1 & 2.7 & 0.1 & 3.5 \\
Rio de Janeiro & 13.9 & 2.5 & 2.2 & 2.1 & 2.7 & 0.1 & 4.0 \\
Rio Grande & 14.4 & 2.5 & 2.2 & 2.1 & 2.7 & 0.1 & 4.5 \\
St. Petersburg & 16.7 & 2.5 & 2.2 & 6.6 & 2.7 & 0.2 & 2.2 \\
Paldiski & 19.8 & 2.5 & 2.2 & 10.0 & 2.7 & 0.3 & 1.9 \\
Kunda & 19.9 & 2.5 & 2.2 & 10.0 & 2.7 & 0.3 & 2.0 \\
Pärnu & 19.7 & 2.5 & 2.2 & 10.0 & 2.7 & 0.3 & 1.8 \\
Ventspils & 22.1 & 2.5 & 2.2 & 12.4 & 2.7 & 0.3 & 1.7 \\
Liepaja & 22.0 & 2.5 & 2.2 & 12.4 & 2.7 & 0.3 & 1.6 \\
Riga & 22.3 & 2.5 & 2.2 & 12.4 & 2.7 & 0.3 & 1.8 \\
Butinge & 14.3 & 2.5 & 2.2 & 4.9 & 2.7 & 0.2 & 1.5 \\
Klaipeda & 14.3 & 2.5 & 2.2 & 4.9 & 2.7 & 0.2 & 1.5 \\
\hline
\end{tabular}


Table A14. Overview of supply chain GHG emissions of torrefied pellets produced from sawmill residues, transported over $500 \mathrm{~km}$ to export ports and including $50 \mathrm{~km}$ feedstock transport, in $\mathrm{kg}$ $\mathrm{CO}_{2}$-eq/t pellets. Components included in the table: 1 . Silviculture and harvest; 2 . Feedstock transport; 3. Pelletizing; 4. Pellet transport; 5. Shipping; 6. Port operations.

\begin{tabular}{cccccccc}
\hline Export Port & Total & $\mathbf{1}$ & $\mathbf{2}$ & $\mathbf{3}$ & $\mathbf{4}$ & $\mathbf{5}$ & $\mathbf{6}$ \\
\hline Savannah & 10.8 & 0.0 & 1.3 & 4.5 & 2.4 & 0.2 & 2.2 \\
Mobile & 11.3 & 0.0 & 1.3 & 4.5 & 2.4 & 0.2 & 2.7 \\
Norfolk & 10.5 & 0.0 & 1.3 & 4.5 & 2.4 & 0.2 & 2.0 \\
Portland & 10.3 & 0.0 & 1.3 & 4.5 & 2.4 & 0.2 & 1.7 \\
Halifax & 7.3 & 0.0 & 1.3 & 1.7 & 2.4 & 0.1 & 1.5 \\
Montreal & 7.3 & 0.0 & 1.3 & 1.7 & 2.4 & 0.1 & 1.6 \\
Quebec & 7.3 & 0.0 & 1.3 & 1.7 & 2.4 & 0.1 & 1.5 \\
Vancouver & 11.1 & 0.0 & 1.3 & 1.7 & 2.4 & 0.1 & 5.4 \\
Prince Rupert & 11.3 & 0.0 & 1.3 & 1.7 & 2.4 & 0.1 & 5.6 \\
Maceio & 7.5 & 0.0 & 1.3 & 0.9 & 2.4 & 0.1 & 2.6 \\
Salvador & 7.6 & 0.0 & 1.3 & 0.9 & 2.4 & 0.1 & 2.7 \\
Rio de Janeiro & 7.9 & 0.0 & 1.3 & 0.9 & 2.4 & 0.1 & 3.1 \\
Rio Grande & 8.4 & 0.0 & 1.3 & 0.9 & 2.4 & 0.1 & 3.5 \\
St. Petersburg & 10.8 & 0.0 & 1.3 & 4.9 & 2.4 & 0.2 & 1.9 \\
Paldiski & 13.6 & 0.0 & 1.3 & 7.9 & 2.4 & 0.2 & 1.6 \\
Kunda & 13.8 & 0.0 & 1.3 & 7.9 & 2.4 & 0.2 & 1.7 \\
Pärnu & 13.6 & 0.0 & 1.3 & 7.9 & 2.4 & 0.2 & 1.6 \\
Ventspils & 15.7 & 0.0 & 1.3 & 10.1 & 2.4 & 0.3 & 1.4 \\
Liepaja & 15.7 & 0.0 & 1.3 & 10.1 & 2.4 & 0.3 & 1.4 \\
Riga & 15.9 & 0.0 & 1.3 & 10.1 & 2.4 & 0.3 & 1.6 \\
Butinge & 8.7 & 0.0 & 1.3 & 3.4 & 2.4 & 0.1 & 1.3 \\
Klaipeda & 8.7 & 0.0 & 1.3 & 3.4 & 2.4 & 0.1 & 1.3 \\
\hline
\end{tabular}

Table A15. Overview of supply chain GHG emissions of torrefied pellets produced from roundwood, transported over $500 \mathrm{~km}$ to export ports and including $50 \mathrm{~km}$ feedstock transport, in $\mathrm{kg} \mathrm{CO}_{2}$ eq/t pellets. Components included in the table: 1 . Silviculture and harvest; 2. Feedstock transport; 3. Pelletizing; 4. Pellet transport; 5. Shipping; 6. Port operations.

\begin{tabular}{cccccccc}
\hline Export Port & Total & $\mathbf{1}$ & $\mathbf{2}$ & $\mathbf{3}$ & $\mathbf{4}$ & $\mathbf{5}$ & $\mathbf{6}$ \\
\hline Savannah & 14.5 & 2.5 & 2.5 & 4.5 & 2.4 & 0.2 & 2.2 \\
Mobile & 15.1 & 2.5 & 2.5 & 4.5 & 2.4 & 0.2 & 2.7 \\
Norfolk & 14.3 & 2.5 & 2.5 & 4.5 & 2.4 & 0.2 & 2.0 \\
Portland & 14.0 & 2.5 & 2.5 & 4.5 & 2.4 & 0.2 & 1.7 \\
Halifax & 11.0 & 2.5 & 2.5 & 1.7 & 2.4 & 0.1 & 1.5 \\
Montreal & 11.1 & 2.5 & 2.5 & 1.7 & 2.4 & 0.1 & 1.6 \\
Quebec & 11.0 & 2.5 & 2.5 & 1.7 & 2.4 & 0.1 & 1.5 \\
Vancouver & 14.9 & 2.5 & 2.5 & 1.7 & 2.4 & 0.1 & 5.4 \\
Prince Rupert & 15.0 & 2.5 & 2.5 & 1.7 & 2.4 & 0.1 & 5.6 \\
Maceio & 11.2 & 2.5 & 2.5 & 0.9 & 2.4 & 0.1 & 2.6 \\
Salvador & 11.4 & 2.5 & 2.5 & 0.9 & 2.4 & 0.1 & 2.7 \\
Rio de Janeiro & 11.7 & 2.5 & 2.5 & 0.9 & 2.4 & 0.1 & 3.1 \\
Rio Grande & 12.1 & 2.5 & 2.5 & 0.9 & 2.4 & 0.1 & 3.5 \\
St. Petersburg & 14.6 & 2.5 & 2.5 & 4.9 & 2.4 & 0.2 & 1.9 \\
Paldiski & 17.4 & 2.5 & 2.5 & 7.9 & 2.4 & 0.2 & 1.6 \\
Kunda & 17.5 & 2.5 & 2.5 & 7.9 & 2.4 & 0.2 & 1.7 \\
Pärnu & 17.4 & 2.5 & 2.5 & 7.9 & 2.4 & 0.2 & 1.6 \\
Ventspils & 19.5 & 2.5 & 2.5 & 10.1 & 2.4 & 0.3 & 1.4 \\
Liepaja & 19.4 & 2.5 & 2.5 & 10.1 & 2.4 & 0.3 & 1.4 \\
Riga & 19.6 & 2.5 & 2.5 & 10.1 & 2.4 & 0.3 & 1.6 \\
Butinge & 12.5 & 2.5 & 2.5 & 3.4 & 2.4 & 0.1 & 1.3 \\
Klaipeda & 12.5 & 2.5 & 2.5 & 3.4 & 2.4 & 0.1 & 1.3 \\
\hline
\end{tabular}




\section{References}

1. European Commission. Directive (EU) 2018/2001 of the European Parliament and of the Countil of 11 December 2018-On the Promotion of the Use of Energy from Renewable Sources (Recast). Available online: https://eur-lex.europa.eu/legal-content/EN/TXT/PDF/?uri=CELEX:32018L2001\&from=EN (accessed on 5 December 2019).

2. Roni, M.S.; Chowdhury, S.; Mamun, S.; Marufuzzaman, M.; Johnson, S.; Lein, W. Biomass Co-Firing Technology with policies, challenges, and opportunities: A global review; 2017. Renew. Sustain. Energy. Rev. 2017, 78, 1089-1101. [CrossRef]

3. European Commission. A Clean Planet for All-A European Strategic Long-Term Vision for A Prosperous, Modern, Competitive and Climate Neutral Economy (COM (2018) 773 Final). Available online: https://eur-lex. europa.eu/legal-content/EN/TXT/PDF/?uri=CELEX:52018DC0773\&from=EN (accessed on 31 January 2019).

4. Thrän, D.; Schaubach, K.; Peetz, D.; Junginger, M.; Mai-moulin, T.; Schipfer, F.; Olsson, O.; Lamers, P. The dynamics of the global wood developments and impact factors. Biofuels Bioprod. Biorefin. 2018, 267-280. [CrossRef]

5. Proskurina, S.; Junginger, M.; Heinimö, J.; Tekinel, B.; Vakkilainen, E. Global biomass trade for energy-Part 2: Production and trade streams of wood pellets, liquid biofuels, charcoal, industrial roundwood and emerging energy biomass. Biofuels Bioprod. Biorefin. 2018, 1-17. [CrossRef]

6. Bioenergy Europe. Statistical Report 2019—Report Pellet; Bioenergy Europe: Brussels, Belgium, 2019.

7. Matzenberger, J.; Kranzl, L.; Tromborg, E.; Junginger, M.; Daioglou, V.; Sheng Goh, C.; Keramidas, K. Future perspectives of international bioenergy trade. Renew. Sustain. Energy Rev. 2015, 43, 926-941. [CrossRef]

8. Thrän, D.; Peetz, D.; Schaubach, K.; Backéus, S.; Benedetti, L.; Bruce, L.; Craggs, R.; Diaz-Chavez, D.; Escobar, J.; Goldemberg, R.; et al. Global wood pellet industry and trade study 2017. Available online: http: //task40.ieabioenergy.com/wp-content/uploads/2013/09/IEA-Wood-Pellet-Study_final-2017-06.pdf (accessed on 9 January 2018).

9. Jonsson, R.; Rinaldi, F. The impact on global wood-product markets of increasing consumption of wood pellets within the European Union. Energy 2017, 133, 864-878. [CrossRef]

10. Johnston, C.M.T.; Van Kooten, G.C. Global trade impacts of increasing Europe' s bioenergy demand. J. For. Econ. 2016, 23, 27-44. [CrossRef]

11. Wild, M.; Visser, L. Biomass Pre-Treatment for Bioenergy-Case Study 1: Biomass Torrefaction; IEA Bioenergy. 2018. Available online: http://itp-fueltreatment.ieabioenergy.com/wp-content/uploads/2018/09/ CS1-Torrefaction.pdf (accessed on 12 June 2019).

12. E3MLab. PRIMES MODEL 2013-2014 detailed model description. Available online: https://ec.europa. eu/clima/sites/clima/files/strategies/analysis/models/docs/primes_model_2013-2014_en.pdf (accessed on 31 January 2019).

13. Simoes, S.; Nijs, W.; Ruiz, P.; Sgobbi, A.; Radu, D.; Bolat, P.; Thiel, C.; Peteves, S. The JRC-EU-TIMES Model-Assessing the Long-Term Role of the SET Plan Energy Technologies; Publications Office of the European Union: Petten, The Netherlands, 2013. [CrossRef]

14. Forsell, N.; Korosuo, A.; Havlík, P.; Valin, H.; Lauri, P.; Gusti, M.; Kindermann, G.; Obersteine, M. Study on Impacts on Resource Efficiency of Future EU Demand for Bioenergy-Task 3: Modelling of Impacts of An Increased EU Bioenergy Demand on Biomass Production; European Commission: Luxembourg, 2016.

15. Stehfest, E.; Van Vuuren, D.; Kram, T.; Bouwman, L.; Alkemade, R.; Bakkenes, M.; Biemans, H.; Bouwman, A.; Den Elzen, M.; Janse, J.; et al. Integrated Assessment of Global Environmental Change with IMAGE 3.0-Model Description and Policy Applications; The Netherlands Environmental Assessment Agency: Hague, The Netherlands, 2014.

16. Buongiorno, J. Global modelling to predict timber production and prices: The GFPM approach. Forestry 2015, 291-303. [CrossRef]

17. Mai-moulin, T.; Visser, L. Sourcing overseas biomass for EU ambitions: Assessing net sustainable export potential from various sourcing countries. Biofuels Bioprod. Biorefin. 2019, 13, 293-324. [CrossRef]

18. Bioenergy Europe. Statistical Report 2018; Bioenergy Europe: Brussels, Belgium, 2018.

19. Welfle, A. Biomass and bioenergy balancing growing global bioenergy resource demands—Brazil's biomass potential and the availability of resource for trade. Biomass Bioenergy 2017, 105. [CrossRef] 
20. Giuntoli, J.; Agostini, A.; Edwards, R.; Marelli, L. Solid and Gaseous Bioenergy Pathways: Input Values and GHG Emissions: Calculated According to the Methodology Set in COM(2016) 767-Compendium; Joint Research Centre: Ispra, Italy, 2017.

21. FutureMetrics. North American Pellet Market Quarterly; FutureMetrics: Betherl, ME, USA, 2018.

22. Giuntoli, J.; Agostini, A.; Edwards, R.; Marelli, L. Solid and Gaseous Bioenergy Pathways: Input Values and GHG Emissions; Joint Research Centre: Ispra, Italy, 2015. [CrossRef]

23. Myhre, G.; Shindell, D.; Bréon, F.-M.; Collins, W.; Fuglestvedt, J.; Huang, J.; Koch, D.; Lamarque, J.; Lee, D.; Mendoza, B.; et al. Anthropogenic and natural radiative forcing. In Climate Change 2013: The Physical Science Basis. Contribution of Working Group I to the Fifth Assessment Report of the Intergovernmental Panel on Climate Change; Cambridge University Press: Cambridge, UK; New York, NY, USA, 2013.

24. Croezen, H.; Vroonhof, J.; Rooijers, F. Welke Nieuwe Energiecentrale in Nederland? Vernieuwd model!; CE, Delft, Netherlands. Available online: https://www.ce.nl/publicaties/download/445 (accessed on 5 December 2019).

25. Clark, A.; Daniels, R.F. Estimating Moisture Content of Tree-Length Roundwood; Pulping/Process and Product Quality Conference; Sheraton: Boston, MA, USA, 2000.

26. U.S. Forest Service. Glossary of Forest Engineering Terms 2019. Available online: https://www.srs.fs.usda. gov/forestops/glossary/\#P (accessed on 6 December 2019).

27. Waddell, K. Available online: https://www.climateactionreserve.org/wp-content/uploads/2011/03/VolumeEquations-Updated-3-25-2011.pdf (accessed on 6 December 2019).

28. Derks, M. Co-Firing White or Torrefied Wood Pellets in the Netherlands?-An Assessment of GHG Emissions and Emission Savings. Master's Thesis, Utrecht University, Utrecht, The Netherlands, 2018.

29. Jonker, J.G.G.; Junginger, M.; Faaij, A. Carbon payback period and carbon offset parity point of wood pellet production in the South-eastern United. GCB Bioenergy 2014, 371-389. [CrossRef]

30. EcoTransIT. Ecological Transport Information Tool for Worldwide Transports; EcoTransIT World Initiative (EWI): Berne/Hannover/Heidelberg, Germany, 2014.

31. Lindholm, E. Energy Use and Environmental Impact of Roundwood and Forest Fuel Production in Sweden; Swedish University of Agricultural Sciences: Uppsala, Sweden, 2010.

32. U.S. Energy Information Administration. Monthly Densified Biomass Fuel Report. 18 December 2018. Available online: https://www.eia.gov/biofuels/biomass/\#table_data (accessed on 24 January 2019).

33. Stuber, D. Forest 2 Market. Global Wood Fiber Prices: 2Q2017 Insights from Forest 2 Market's Western Hemisphere Benchmark. Available online: https://blog.forest2market.com/global-wood-fiber-prices-2q2017insights-from-forest2markets-western-hemisphere-benchmark (accessed on 9 May 2019).

34. Teder, M.; Raudsaar, M. Functioning of Estonian Roundwood Market. Available online: http://www. idanmetsatieto.info/tiedostot/tiedotteet/Estonia_BNFSG_Raudsaar.pdf (accessed on 11 June 2019).

35. Baltpool. Available online: https://www.baltpool.eu/en/review-of-timber-market-2018/ (accessed on 20 June 2019).

36. Indufor. Forest Industry in Finland \& Russia: Opportunities \& Challenges. Available online: https: //induforgroup.com/forest-industry-in-finland-russia-opportunities-challenges/ (accessed on 20 June 2019).

37. Visser, L.; Hoefnagels, R.; Junginger, M. Wood pellet supply chain costs-A review and cost optimization analysis. Renew. Sustain. Energy Rev. 2020, 118, 109506. [CrossRef]

38. Thek, G.; Obernberger, I. Wood pellet production costs under Austrian and in comparison to Swedish framework conditions. Biomass Bioenergy 2004, 27, 671-693. [CrossRef]

39. Obernberger, I.; Thek, G. The Pellet Handbook; Earthscan: London, UK; Washington, DC, USA, 2010.

40. Sikkema, R.; Junginger, M.; Pichler, W.; Hayes, S.; Faaij, A.P.C. In the field the international logistics of wood pellets for heating and power production in Europe: Costs, energy-input and greenhouse gas balances of pellet consumption in Italy, Sweden and the Netherlands. Biofuels Bioprod. Biorefin. 2010, 132-153. [CrossRef]

41. Uasuf, A.; Becker, G. Wood pellets production costs and energy consumption under different framework conditions in Northeast Argentina. Biomass Bioenergy 2011, 35, 1357-1366. [CrossRef]

42. Mobini, M.; Meyer, J.; Trippe, F.; Sowlati, T.; Fröhling, M.; Schultmann, F. Assessing the integration of torrefaction into wood pellet production. J. Clean. Prod. 2014, 78, 216-225. [CrossRef]

43. Ehrig, R.; Behrendt, F.; Wörgetter, M.; Strasser, C. Economics and Price Risks in International Pellet Supply Chains; Springer: Cham, Switzerland; Heidelberg, Germany; New York, NY, USA; Dordrecht, The Netherlands; London, UK, 2014. 
44. Pirraglia, A.; Gonzalez, R.; Saloni, D. Techno-economical analysis of wood pellets production for U.S. manufacturers. BioResources 2010, 5, 2374-2390.

45. Tumuluru, J.S.; Sokhansanj, S.; Hess, J.R.; Wright, C.T.; Boardman, R.D. A review on biomass torrefaction process and product properties for energy applications. Ind. Biotechnol. 2011. [CrossRef]

46. Bergman, P.C.A. Combined Torrefaction and Pelletisation: The TOP Process. Available online: https: //www.ecn.nl/docs/library/report/2005/c05073.pdf (accessed on 9 January 2018).

47. International Energy Agency (IEA). The Future of Trucks. Available online: https://webstore.iea.org/ download/direct/288 (accessed on 24 April 2019).

48. Gonzales, D.; Searcy, E.M.; Ekşioĝlu, S.D. Cost analysis for high-volume and long-haul transportation of densified biomass feedstock. Transp. Res. Part A Policy Pract. 2013, 49, 48-61. [CrossRef]

49. Dowling, T.N.; Bolding, M.C.; Aust, W.M.; Fox, T.R.; Dowling, T. An Analysis of Log Truck Turn Times at Harvest Sites and Mill Facilities An Analysis of Log Truck Turn Times at Harvest Sites and Mill Facilities; Virginia Polytechnic Institute and State University: Blacksburg, VA, USA, 2010.

50. Conrad, J.L. Costs and challenges of log truck transportation in Georgia, USA. Forests 2018, 9, 650. [CrossRef]

51. Thompson, J.D.; Klepac, J.; Sprinkle, W. Trucking Characteristics for An In-Woods Biomass Chipping Operation. In Proceedings of the 35th Council on Forest Engineering Annual Meeting, New Bern, NC, USA, 9-12 September 2012; pp. 1-4.

52. Hoefnagels, R.; Searcy, E.; Cafferty, K.; Junginger, T.C.M.; Jacobson, J.; Faaij, A. Lignocellulosic feedstock supply systems with intermodal and overseas transportation. Biofuels Bioprod. Biorefin. 2014, 8, 794-818. [CrossRef]

53. Ports.Com. Sea Route \& Distance 2018. Available online: http://ports.com/sea-route/port-of-rotterdam, netherlands/port-of-savannah, united-states/ (accessed on 9 January 2018).

54. Dafnomilis, I.; Lodewijks, G.; Junginger, M.; Schott, D.L. Evaluation of wood pellet handling in import terminals. Biomass Bioenergy 2018, 117, 10-23. [CrossRef]

55. International Maritime Organisation. Third IMO Greenhouse Gas Study 2014; International Maritime Information: London, UK, 2015.

56. Günthner, W.A.; Tilke, C.; Rakitsch, S. Energy efficiency in bulk material handling. Bulk Solids Handl. 2010, 30, 138-142.

57. Di Fulvio, F.; Forsell, N.; Lindroos, O.; Korosuo, A.; Gusti, M. Spatially explicit assessment of roundwood and logging residues availability and costs for the EU28. Scand. J. For. Res. 2016, 31, 691-707. [CrossRef]

58. Wang, X.; Bi, H.; Ximenes, F.; Ramos, J.; Li, Y. Product and residue biomass equations for individual trees in rotation age pinus radiata stands under three thinning regimes in New South Wales, Australia. Forests 2017, 439. [CrossRef]

59. Forest Research. Tools \& Resources-Moisture Content 2018. Available online: https://www.forestresearch. gov.uk/tools-and-resources/biomass-energy-resources/reference-biomass/facts-figures/moisture-content/ (accessed on 11 October 2018).

60. Verkerk, P.J.; Levers, C.; Kuemmerle, T.; Lindner, M.; Valbuena, R.; Verburg, P.H.; Zudin, S. Mapping wood production in European forests. For. Ecol. Manage. 2015, 357, 228-238. [CrossRef]

61. European Commission. Available online: https:/ec.europa.eu/energy/sites/ener/files/documents/biosustain report_final.pdf (accessed on 14 May 2019).

62. Dale, V.H.; Kline, K.L.; Parish, E.S.; Cowie, A.L.; Emory, R.; Malmsheimer, R.W.; Slade, R.; Smith, C.T.; Wigley, T.B.; Bentsen, N.S.; et al. Status and prospects for renewable energy using wood pellets from the southeastern United States. GCB Bioenergy 2017, 1-10. [CrossRef]

63. ArcGIS. World Railroads. 2019. Available online: https://www.arcgis.com/home/item.html?id= 5ef3425348954c84a45860bcf86c78ab (accessed on 6 June 2019).

64. Geofabrik. OpenStreetMap Data Extracts. 2019. Available online: http://download.geofabrik.de/ (accessed on 15 April 2019).

65. Instituto Brasiliero de Geografia e Estatistica (IBGE). Monitoramento da Cobertura e Uso da Terra. 2016. Available online: https://www.ibge.gov.br/geociencias/informacoes-ambientais/cobertura-e-uso-da-terra/ 15831-cobertura-e-uso-da-terra-do-brasil.html?=\&t=downloads (accessed on 4 September 2019).

66. Potapov, P.; Yaroshenko, A.; Turubanova, S.; Dubinin, M.; Laestadius, L.; Thies, C.; Aksenov, D.; Egorov, A.; Yesipova, Y.; Glushkov, I.; et al. Mapping the world' s intact forest landscapes by remote sensing. Ecol. Soc. 2008, 13, 51. [CrossRef] 
67. Fundação Nacional do Índio. Mapas. Available online: http://www.funai.gov.br/index.php/servicos/ geoprocessamento (accessed on 11 September 2019).

68. Ministério do Meio Ambiente. Áreas Protegidas. Available online: https://www.mma.gov.br/areas-protegidas. html (accessed on 11 September 2019).

69. Forest2Market. Brazil's Changing Role in the Global Pulp Market. 2017. Available online: https://www. forest2market.com/blog/brazils-changing-role-in-the-global-pulp-market (accessed on 20 December 2019).

70. Abt, K.L.; Abt, R.C.; Galik, C. Effect of bioenergy demands and supply response on markets, carbon, and land use. For. Sci. 2012, 58, 523-539. [CrossRef]

71. Kim, S.J.; Baker, J.S.; Sohngen, B.L.; Shell, M. Cumulative global forest carbon implications of regional bioenergy expansion policies. Resour. Energy Econ. 2018, 53, 198-219. [CrossRef]

72. Strauss, W. Industrial Wood Pellets in Japan Market Drivers and Potential Demand. In Proceedings of the 6th Annual Exporting Pellets Conference, Miami Beach, FL, USA, 8-8 November 2016.

73. Drax. Carbon Dioxide Now Being Captured in First of Its Kind BECCS Pilot. 2019. Available online: https://www.drax.com/press_release/world-first-co2-beccs-ccus/ (accessed on 4 February 2020).

74. Vera, I.; Hoefnagels, R. Modeling and analysis of multi-output biorefineries with study for The Netherlands. Biofuels Bioprod. Biorefin. 2019, 1-27. [CrossRef]

75. Centralas Statistikas Parvaldes Datubazes. MEG050. In Average Purchase Prices of Wood (EUR $/ \mathrm{m}^{3}$ (Excluding VAT)); 2018. Available online: https://data1.csb.gov.lv/pxweb/en/lauks/lauks_mezsaimn_mezizstr_ikgad/ MEG050.px/ (accessed on 20 June 2019).

76. European Commission. Consumer Prices of Petroleum Products (Inclusive of Duties and Taxes). 2019. Available online: http://ec.europa.eu/energy/maps/maps_weekly_oil_bulletin/latest_Oil_Prices_DIE.pdf (accessed on 5 June 2019).

77. U.S. Energy Information Administration. Gasoline and Diesel Fuel Update. 2019. Available online: https://www.eia.gov/petroleum/gasdiesel/ (accessed on 10 May 2019).

78. XE. XE Currency Converter: 1 USD to EUR = 0.886807 Euros. 2019. Available online: https://www.xe.com/ currencyconverter/convert/?Amount=1\&From $=\mathrm{USD} \& \mathrm{To}=\mathrm{EUR} \% 0 \mathrm{~A}$ (accessed on 5 June 2019).

79. Natural Resources Canada. Average Retail Prices for Diesel in Canada. 2019. Available online: http: //www2.nrcan.gc.ca/eneene/sources/pripri/prices_byyear_e.cfm?ProductID=5\#pricesTable (accessed on 10 May 2019).

80. XE. XE Currency Converter: 1 CAD to EUR = 0.662810 Euros. 2019. Available online: https://www.xe.com/ currencyconverter/convert/?Amount=1\&From $=$ CAD\&To=EUR\%0A (accessed on 5 June 2019).

81. GlobalPetrolPrices.com. Brazil Diesel Prices, Liter. Available online: https://www.globalpetrolprices.com/ Brazil/diesel_prices/ (accessed on 10 May 2019).

82. XE. XE Currency Converter: 1 BRL to EUR $=0.230170$ Euros. 2019. Available online: https://www.xe.com/ currencyconverter/convert/?Amount=1\&From=BRL\&To=EUR (accessed on 5 June 2019).

83. GlobalPetrolPrices.com. Russia Diesel Prices, Liter. 2019. Available online: https://www.globalpetrolprices. com/Russia/diesel_prices/ (accessed on 5 June 2019).

84. XE. XE Currency Converter: 1 RUB to EUR =0.0136261 Euros. 2019. Available online: https://www.xe.com/ currencyconverter/convert/?Amount=1\&From=RUB\&To=EUR\%0A (accessed on 5 June 2019).

85. Eurostat. Hourly Labour Costs. 2019. Available online: https://ec.europa.eu/eurostat/statistics-explained/ index.php/Hourly_labour_costs\%0A (accessed on 28 May 2019).

86. The Conference Board. International Comparisons of Hourly Compensation Costs in Manufacturing, 2016—Summary Tables. 2018. Available online: https://www.conference-board.org/ilcprogram/index.cfm? $\mathrm{id}=38269$ (accessed on 8 August 2018).

87. Trading Economics. Available online: https://tradingeconomics.com/russia/wages-in-manufacturing (accessed on 5 June 2019).

88. CBS StatLine. Aardgas En Elektriciteit, Gemiddelde Prijzen Van Eindverbruiker. 2019. Available online: https: //opendata.cbs.nl/statline/\#/CBS/nl/dataset/81309NED/table?ts=1557225400290 (accessed on 5 June 2019).

89. U.S. Energy Information Administration. Short-Term Energy Outlook. 2019. Available online: https: //www.eia.gov/outlooks/steo/report/electricity.php (accessed on 5 June 2019).

90. Natural Resources Canada. Electricity Facts. 2018. Available online: https://www.nrcan.gc.ca/energy/facts/ electricity/20068 (accessed on 24 May 2019). 
91. GlobalPetrolPrices.com. Brazil Electricity Prices. 2018. Available online: https://www.globalpetrolprices. com/Brazil/electricity_prices/\%0A (accessed on 24 May 2019).

92. Eurostat. Electricity Prices for Non-Household Consumers-Bi-Annual Data (from 2007 Onwards). 2019. Available online: http://appsso.eurostat.ec.europa.eu/nui/show.do?dataset=nrg_pc_205\&lang=en $\% 0 \mathrm{~A}$ (accessed on 5 June 2019).

93. CEIC. Russia Average Producer Price: Electricity and Thermal Energy. 2019. Available online: https: //www.ceicdata.com/en/russia/average-producer-price-electricity-and-thermal-energy\%0A (accessed on 5 June 2019).

94. BIX Bunker Index. BIX World indices. 2019. Available online: https://www.bunkerindex.com/ (accessed on 7 May 2019).

95. Bimco. Dry Bulk Shipping: Q1 Requires Careful Handling as Seasonal Cargo Demand Drops. 2019. Available online: https://www.bimco.org/news/market_analysis/2018/20180220_drybulksmoo_2018_01 (accessed on 24 May 2019).

96. Svanberg, M.; Olofsson, I.; Flodén, J.; Nordin, A. Bioresource technology analysing biomass torrefaction supply chain costs. Bioresour. Technol. 2013, 142, 287-296. [CrossRef] [PubMed]

97. Wang, L.; Barta-Rajnai, E.; Skreiberg, Ø.; Khalil, R.; Czégény, Z.; Jakab, E.; Barta, Z.; Grønli, M. Effect of torrefaction on physiochemical characteristics and grindability of stem wood, stump and bark. Appl. Energy 2018, 227, 137-148. [CrossRef]

98. EFI-European Forest Institute. Wood Production Maps for European Forests. Available online: https: //www.efi.int/knowledge/maps/woodproduction (accessed on 3 September 2019).

99. Stolbovoi, V. Soil carbon in the forests of Russia. Mitig. Adapt. Strateg. Glob. Chang. 2006, 2, $203-222$. [CrossRef]

100. FAO. The Russian Federation Forest Sector-Outlook Study to 2030; Rome, Italy. Available online: http://www.fao.org/3/i3020e/i3020e00.pdf (accessed on 14 September 2019).

101. Power, K.; Gillis, M. Canada's Forest Inventory 2001; Canadian Forest Service/Pacific Forestry Centre: Victoria, BC, Canada, 2006.

102. Hember, R.A.; Kurz, W.A.; Coops, N.C. Global Biogeochemical Cycles. Glob. Biogeochem. Cycles 2014, 134-158. [CrossRef]

103. Conservation Biology Institute. Canada's Intact Forest Landscapes. 2018. Available online: https: //databasin.org/articles/c6c75b7c47fe4965a5ba55670fd28983 (accessed on 4 September 2019).

104. USDA Forest Service. Download National Datasets. Available online: https://data.fs.usda.gov/geodata/edw/ datasets.php?xmlKeyword=FIA (accessed on 4 September 2019).

105. Heilman, G.E., Jr.; Strittholt, J.R.; Slosser, N.C.; Dellasala, D.A. Forest fragmentation of the conterminous united states: Assessing forest intactness through road density and spatial characteristics. Bioscience 2002, 52, 411-422. [CrossRef]

106. Conservation Biology Institute. Forest Intactness Database. 2001. Available online: https://consbio.org/ products/projects/forest-intactness-database (accessed on 13 September 2019).

107. FAO. Mean Annual Volume Increment of Selected Industrial Forest Plantation Species by L. Ugalde E O. Pérez; Forest Plantation Thematic Papers, Working Paper 1. Forest Resources Development Service; Forest Resources Division, FAO: Rome, Italy, 2001.

108. FAO. Potential Forest Species for Plantations in Brazilian Amazonia. Available online: http://www.fao.org/3/ xii/0537-b1.htm (accessed on 13 September 2019).

109. World Forest Institute. Brazil. Available online: https://www.worldforestry.org/wp-content/uploads/2015/11/ brazil-m.camargo.pdf (accessed on 11 September 2019).

110. Orangeville, L.D.; Houle, D.; Duchesne, L.; Phillips, R.P.; Bergeron, Y.; Kneeshaw, D. Beneficial effects of climate warming on boreal tree growth may be transitory. Nat. Commun. 2018, 1-10. [CrossRef]

111. Parks, C. Available online: http://parkscanadahistory.com/publications/fact-sheets/eng/ecozones.pdf (accessed on 11 September 2019).

(C) 2020 by the authors. Licensee MDPI, Basel, Switzerland. This article is an open access article distributed under the terms and conditions of the Creative Commons Attribution (CC BY) license (http://creativecommons.org/licenses/by/4.0/). 